\title{
A 15-year hail streak climatology for the Alpine region
}

\author{
L. Nisi ${ }^{1,2,3,4}$, A. Hering ${ }^{4}$, U. Germann ${ }^{4}$ and O. Martius ${ }^{1,2,3}$ \\ ${ }^{1}$ University of Bern, Oeschger Centre for Climate Change Research, Bern, Switzerland \\ ${ }^{2}$ University of Bern, Institute of Geography, Bern, Switzerland \\ ${ }^{3}$ University of Bern, Mobiliar Lab for Natural Risks, Bern, Switzerland \\ ${ }^{4}$ Federal Office of Climatology and Meteorology MeteoSwiss, Locarno-Monti, Switzerland
}

\begin{abstract}
In this study, we present a unique 15-year hail streak climatology for Switzerland based on volumetric radar reflectivity. Two radar-based hail detection products and an automatic thunderstorm tracking algorithm were reprocessed for the extended convective season (April - September) between 2002 and 2016. More than 1.1 million convective cells were automatically tracked over the full radar domain, and over 191'000 storms and 31'000 hail streaks in the considered subdomain were selected for analysis following consistency and robustness tests.
\end{abstract}

The year-to-year variability in the number of hail storms reveals two types of convective seasons: i) few seasons with a hail frequency far above the average and ii) all other years with an average number of hail storms. A high number of hail storms in a particular year is not correlated with a higher number of convective storms in general, but is related to a greater fraction of severe storms.

Convection initiation, hail initiation, and hail frequency maxima are located along the southern and northern foothills over the pre-Alpine area and over the Jura mountains. Few hail streaks are present over the Alpine main ridge. Hail streak frequency and location is found to be strongly dependent on the synoptic-scale weather regimes. This is important for monthly and seasonal outlooks, as well as for climate modelling.

Analysis of storm life cycles shows that: i) the majority of hail swaths contains only a single hail streak, ii) severe storms follow a more rapid evolution during their initial stages than do less severe storms, and iii) severe storms produce more spatially extended hail streaks.

Finally, significant seasonal and diurnal cycles are present in most of the considered storm characteristics.

This article has been accepted for publication and undergone full peer review but has not been through the copyediting, typesetting, pagination and proofreading process, which may lead to differences between this version and the Version of Record. Please cite this article as doi: 10.1002/qj.3286 
Keywords: Hail, Hail streak, Hail swath, Convection, Thunderstorm, Weather radar, Thunderstorms Tracking, Switzerland, Alps

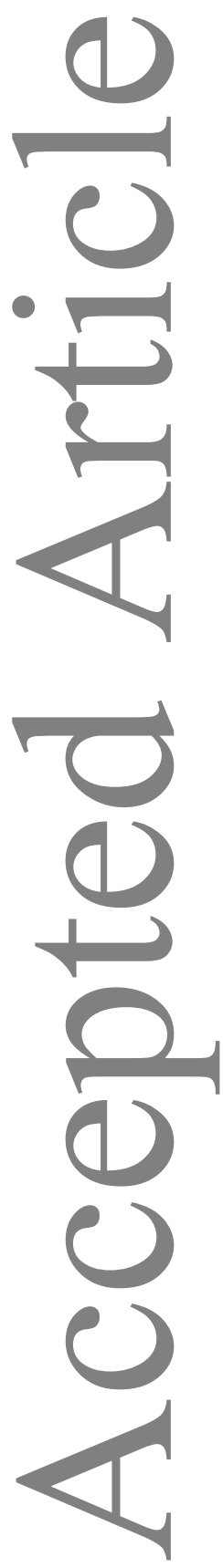




\section{Introduction}

Severe weather monitoring and forecasting in areas with complex orography like the Alps is a challenging task. The predictability of convective precipitation, especially if it is not organized in large-scale structures (e.g. fronts), is very limited because of its chaotic nature and its high spatial and temporal variability (e.g. Wilson et al., 1998; Hanley et al., 2011; López et al., 2007; Melcón et al., 2017). For these reasons, severe weather climatologies continue to provide an important source of information for operational forecasting and warning purposes (e.g. Johns and Doswell, 1992), for climate monitoring (e.g. Kunkel et al., 2013), for the verification of numerical weather prediction (NWP) model output (e.g. Rajeevan et al., 2010; Spiridonov et al., 2010; Sokol et al., 2016), and for applications in the insurance sector (Botzen et al., 2010).

During the last decades, hail climatologies based mainly on human observations as well as on hailpad networks have been compiled in several different countries. A comprehensive overview for Europe is provided by Punge and Kunz (2016). The increasing availability of "long-term" volumetric weather-radar datasets opens up new opportunities for hail climatology studies. Radar-based hail detection algorithms offer a viable means of investigating hail in areas where traditional observation networks are not available, as is the case in Switzerland. Furthermore, radar-based approaches cover large areas and provide data at high spatio-temporal resolution (e.g. Kunz and Kugel, 2015; Martius et al., 2017). Radar-based hail detection algorithms have been used to compile gridded hail climatologies in different countries (e.g. Kunz and Puskeiler, 2010, Cintineo et al., 2012; Puskeiler, 2013, Skripniková and Řezáčová, 2014, Kunz and Kugel, 2015, Lukach et al., 2017), including the Swiss alpine area (Nisi et al., 2016). Such gridded analyses provide information about the spatio-temporal distribution of hail, as well as about yearly, seasonal, and diurnal cycles. These datasets provide a Eulerian perspective on a pixel basis with typical spatial resolution of $1-4 \mathrm{~km}^{2}$. Detailed statistics on convection initiation, storm intensification, hail initiation and decay, and storm footprints require Lagrangian information regarding the life cycles of individual storms. Thunderstorms produce hail in the form of hail streaks (hereafter HST). These are spatially coherent areas with hail on the ground (Changnon, 1970) inside a storm path (hereafter SPA). During its

life cycle, a single thunderstorm can produce several HSTs. According to Changnon 
(1970), the envelope encompassing all HSTs of a storm is called a hail swath (hereafter HSW).

The creation of Lagrangian thunderstorm-object datasets is computationally challenging and requires an automatic storm-tracking system. For this reason, few studies to date have included large thunderstorm datasets in their analysis. For example, Kelly et al. (1985) used hail and wind reports to compute a climatology of nontornadic severe thunderstorms over the U.S. Thunderstorms were clustered according to related severe weather reports. Because of the limited spatio-temporal resolution of the available data, a detailed study of thunderstorm life cycles was not possible. Due to their high spatio-temporal resolution, weather radar data allow for the detection of both SPAs and HSWs. For example, Basara et al. (2007) compiled a HSW occurrence map over the U.S. for the time period 20012003 using a semi-automatic procedure that included a hail swath detection algorithm. Automatic storm detection algorithms applied to radar data allow for the processing of large datasets. For example, an automated object-based approach was used by Wapler et al. (2016) to detect and track more than $37^{\prime} 000$ mesocyclones over Germany between 2012 and 2014.

In this study, an automatic thunderstorm tracking system has been used to reprocess 15 years of homogeneous, full resolution volumetric radar data. With the addition of hail information provided by two radar-based hail detection algorithms, a unique database of more than 1.1 million thunderstorms has been compiled. After consistency and robustness filtering (see sections 3.3 and 3.4), more than 191'000 storms and 31'000 hail streaks have been included in the analysis.

The aim of this study is to characterize thunderstorms and HSWs over Switzerland and adjacent areas. Specifically, the following questions will be addressed: (i) Where do different storm types (non-hail storms, hail storms, severe hail storms) occur? (ii) Are there differences in the life cycles of different storm types and are there differences in the life cycles of storms depending on the synoptic-scale weather conditions? (iii) Are there seasonal or diurnal variations in the geometrical characteristics of SPAs and HSTs? 


\section{Domain and datasets}

\subsection{Investigation area}

Part of our investigation area is located in the complex orography of the Alps (Figure 1), where the terrain ranges from 100 to $>4000 \mathrm{~m}$ a.s.l. The region under investigation is covered by three radars, the Albis, La Dôle and Monte Lema, located in the northeastern, western, and southern parts of Switzerland (Figure 1). The location of important topographic entities, namely the Jura mountains, the pre-Alpine area, and the foothills, are illustrated in Figure 1 in Nisi et al. (2016).

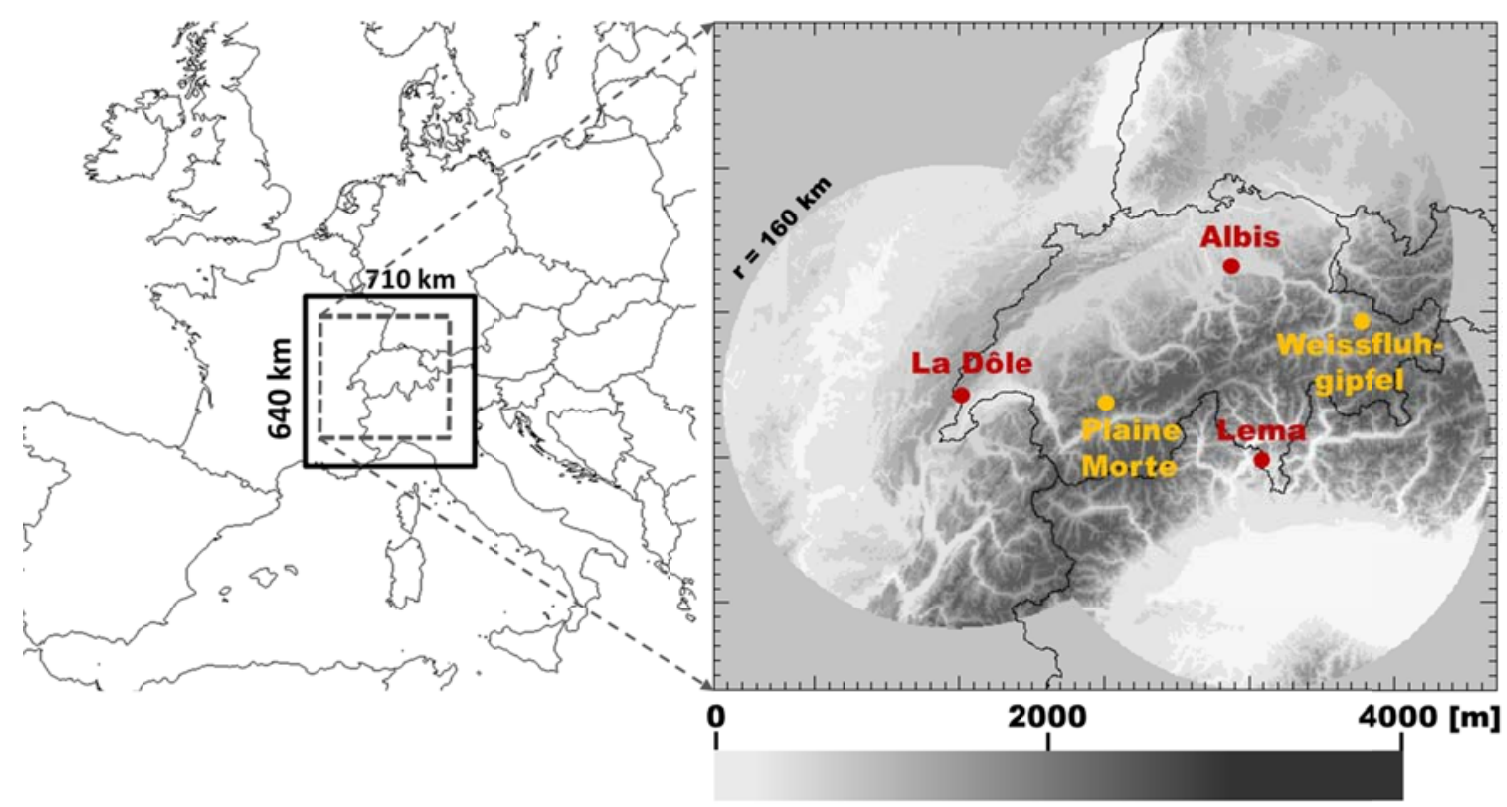

Figure 1: The investigation area of this study is indicated on the left. On the right, the topography and the locations of the three radars used in this study are shown in red. The orange dots indicate the new radar sites that were added in 2014 and 2016, but are not considered in this study.

\subsection{Radar observations}

This study uses three C-band radars from the MeteoSwiss radar network. Between 2011 and 2012, all three C-band Doppler radars (Joss et al., 1998) were replaced with dualpolarisation radars (Germann et al, 2015). Two additional radar sites were added in 2014 and 2016 (Figure 1). Because of their limited datasets, these two radar sites were not included in this study. The dataset covers 15 years (2002-2016), with a spatio-temporal 
resolution of $1 \mathrm{~km}^{2}$ and 5 minutes. More details on the radar data are summarized in Table 1 in Nisi et al. (2016) and presented extensively in Joss et al. (1998) and in Germann et al. (2006, 2016, 2017). This study uses the same single polarisation radar-based hail detection products as presented in Nisi et al. (2016), namely the Probability of Hail (hereafter POH) and the Maximum Expected Severe Hail Size (hereafter MESHS). Both products are described in detail in section 3.1.

\subsection{Model data}

The radar-based hail detection algorithms require information on the freezing level height (hereafter H0). This information is extracted from the analysis data of the regional numerical weather prediction (NWP) model COnsortium for Small-scale MOdelling (COSMO-CH; http://cosmo-model.org/). COSMO-CH is a non-hydrostatic, regional, high-resolution numerical weather prediction model operated by MeteoSwiss. Due to model changes in the investigation period, the horizontal resolutions employed in this study are $6.6 \times 6.6 \mathrm{~km}^{2}$ (COSMO-7; 04.2002-03.2008), 2.2 x $2.2 \mathrm{~km}^{2}$ (COSMO-2; 04.2008-08.2016) and 1x1 km² (COSMO-1, 09.2016). The temporal resolution is 1 hour. These changes and other model modifications had no significant effects on the H0 fields (see Nisi et al., 2016 for more details).

\subsection{Weather Type classification}

This study uses a weather type (hereafter WT) classification (Weusthoff, 2011) that is based on the geopotential, the mean wind speed and the wind direction on $500 \mathrm{hPa}$ over central Europe taken from the ERA-Interim dataset (Dee et al. 2011). WTs are defined on a daily basis and are classified according to the synoptic situation over Switzerland. 8 main flow directions (WT1-WT8), low pressure (WT9) and high pressure (WT10) are provided (Weusthoff, 2011).

\section{Methods}

\subsection{Probability of Hail (POH) and Maximum Expected Severe Hail Size (MESHS)}


POH and MESHS are empirical, radar-based hail detection algorithms. Both are extensively described in chapter 3.1 and 3.2 of Nisi et al. (2016), where algorithms, respective equations and verifications scores are provided. Here, a short summary of the most important information is provided. $\mathrm{POH}$ uses the vertical distance between the $45 \mathrm{dBZ}$ echo top height (hereafter ET45) and the $\mathrm{H} 0$ as an indicator for the presence of falling hailstones on the ground following Waldvogel et al. (1979). ET45 is the highest altitude at which a radar reflectivity of $45 \mathrm{dBZ}$ or more is detected (Donaldson, 1961). POH provides a probability estimate of the presence of hail of any size on the ground, with a scale ranging from $0 \%$ (no hail; ET45 - H0 $<1.65 \mathrm{~km}$ ) to $100 \%$ (hail; ET45 - H0 $>5.5 \mathrm{~km}$ ). POH should not be confused with the Probability of Severe Hail (POSH; Witt et al., 1998), which is estimated from HO and the Severe Hail Index parameter (SHI), a thermally weighted vertical integration of a reflectivity profile of a storm cell.

MESHS provides an estimation of the maximum size of hailstones on the ground for hailstone diameters equal to or larger than $2 \mathrm{~cm}$. MESHS is derived from the difference between the $50 \mathrm{dBZ}$ echo top height (hereafter ET50) and H0 (Treloar, 1998). MESHS should not be confused with the Maximum Estimated Size of Hail (MESH; Witt et al., 1998), which represents the square root of SHI.

$\mathrm{POH}$ and MESHS are not based on the direct measurement/observation of hail. However, validations against insurance loss data (e.g. Skripniková and Řezáčová, 2014; Kunz and Kugel, 2015; Morel 2014; Nisi et al., 2016) show that radar-based algorithms are reliable proxies for hail detection. In Nisi et al. (2016), POH damage reports from an automobile insurance company are used as an independent dataset to validate $\mathrm{POH}$.

Verification results confirm that radar-based hail detection algorithms provide valuable information on hail probability. Indeed, for Switzerland, $\mathrm{POH}$ values of $80 \%$ or higher yield a best critical success index (CSI) with a probability of detection (POD) higher than 0.9 and a false alarm rate (FAR) of 0.5 or less. It should be noted that cars are damaged only by severe hail sizes (i.e. $\geq 2 \mathrm{~cm}$ ). A verification with insurance crop losses, which can result from smaller hailstones (e.g. $0.5-1 \mathrm{~cm}$ ), will probably yield a smaller FAR (Saltikoff et al., 2010; Delobbe et al., 2005). Due to very scarce hailstone size ground observations, a comprehensive validation of the MESHS hailstone size estimates for Switzerland is currently missing. However, first comparisons with novel crowd-sourced hail size information show a good hailstone size agreement in the mean, but also reveal substantial variance in hail size estimates (Betschart and Hering, 2012; Noti 2016). This is one reason to use hailstone size 
classes rather than very detailed size information. Three thresholds are used to define hail severity classes: $\mathrm{POH} \geq 80 \%$, MESHS $\geq 2 \mathrm{~cm}$ and MESHS $\geq 4 \mathrm{~cm}$. The $\mathrm{POH} \geq 80 \%$ class includes all hail storms, regardless of the hailstone size. The MESHS $\geq 2 \mathrm{~cm}$ and MESHS $\geq 4$ cm classes include only severe hail storms. The POH and MESHS versions by Foote et al. (2005) and Joe et al. (2004), respectively, have been implemented operationally at MeteoSwiss since 2009 and are used in this study to reprocess radar data between 2002 and 2016.

\subsection{Thunderstorms Radar Tracking (TRT)}

TRT is a 3D multiple-radar tracking algorithm for thunderstorms (Hering et al., 2008; Rotach et al., 2009). It is used operationally at MeteoSwiss for severe thunderstorm warnings. Its purpose is (1) to detect the position of thunderstorms, (2) to classify their severity according to thresholds of radar-based parameters (VIL, vertically integrated liquid, Greene et al., 1972; ET45 and Max Echo, Joss et al., 1998) and (3) to extrapolate the position for the next 60 min based on Lagrangian persistence rules. TRT is used in this study to identify ordinary and severe thunderstorm paths.

TRT is based on a dynamic thresholding scheme that permits the identification of each convective storm by means of individual thresholds (Crane, 1979). Each storm is identified based on a reflectivity threshold $(36-48 \mathrm{dBZ})$ that separates it from nearby storms using the Max Echo product. The varying thresholds are particularly important for detecting and tracking convective storms at different stages in the life cycle with the same algorithm. Furthermore, single storms embedded in squall lines or other multi-storm clusters can be tracked individually.

TRT is a two-step algorithm: a first part provides 2D storm-objects and related geographical and geometric information ("tracking"). A second part estimates the severity of detected storms by including 3D radar data ("ranking"). The TRT output from the first step is used to reprocess radar data and combine the track information with $\mathrm{POH}$ and MESHS data. For a detailed explanation of the TRT algorithm, please refer to Hering et al. (2004), Hering et al. (2008), Rotach et al. (2009) and Nisi et al. (2014).

\subsection{Creating a thunderstorms dataset}


The analysis covers the extended convective season from April to September from 2002 to 2016. In this 15-year time span, the input data quality from both the radar and COSMO$\mathrm{CH}$ is high and fairly homogeneous. The latest updated operational versions of the TRT, $\mathrm{POH}$ and MESHS algorithms have been used to reprocess over 47 million scans $(\sim 2.3$ million volumetric scans) from the Albis, Monte Lema and La Dôle radars. Reprocessing the data with the latest algorithms maximises the homogeneity of the final products. Composite products are created directly from the polar radar volumes. A dedicated algorithm creates each composite pixel by taking account of original measurements from all involved radars. Data gates from each of the available radar polar volumes are collected and then averaged individually according to their altitude. Then, all available single radar data columns are combined into a single column (each radar has a weight equal to 1). For echo top products, the averaged data at different heights in the single vertical column are processed. Successively, a top-down approach searches for reflectivity higher than a given threshold (e.g. 45 or $50 \mathrm{dBZ}$ ) at the highest altitude. If no reflectivity equal to the given threshold is found, linear interpolation is applied. Vertical resolution is 200 meters.

Figure 2 shows the procedure used to create the hail storm database. A first version was already presented in Nisi et al. (2016). Added here is the reprocessing of the Max Echo product and the tracking part of TRT. The last step is the matching of the TRT tracks with the $\mathrm{POH}$ and MESHS products. A dedicated algorithm matches the POH and MESHS fields with the TRT storms for every 5-minute interval (Figure 3). The distribution of $\mathrm{POH}$ and MESHS values inside the borders of the detected storms was stored in the database. 


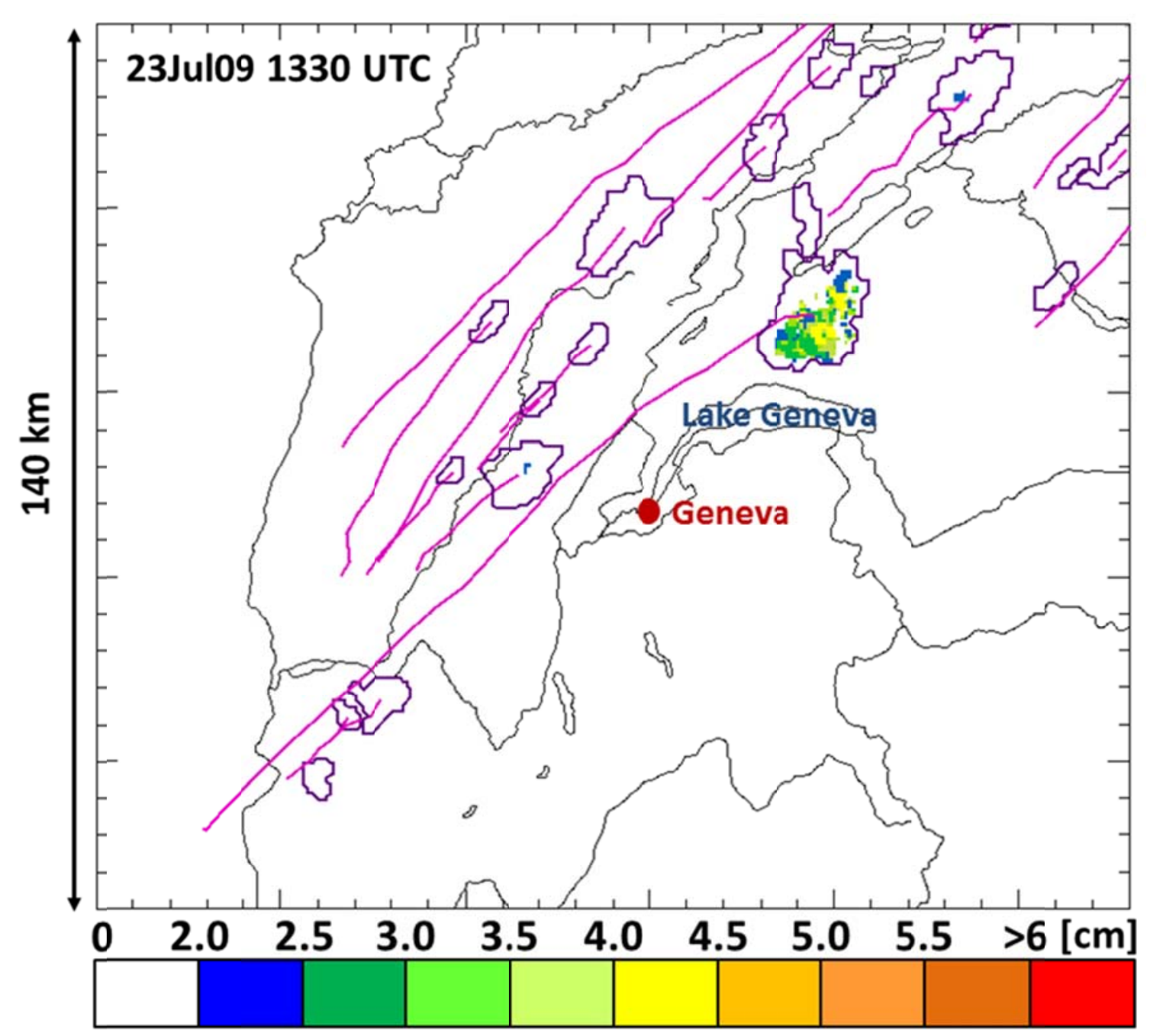

Figure 3: Example of TRT storm tracks and hail detection. A multi-cell cluster is detected, but only the storm located to the north of the lake of Geneva produced significant hail. Colours inside the storms show the maximum hail size provided by MESHS.

The thunderstorm database contains more than 1.1 million files (radial distance full radar domain: $230 \mathrm{~km}$ former generation and $246 \mathrm{~km}$ current generation); each file contains the entire life cycle of a single storm. The list of storm parameters stored in the files is provided in Table 2 in Appendix 1. The fully digital processing of the data guarantees homogeneity and objectivity. The result is a unique database for the Alpine area that offers many new research opportunities. Schemm et al. (2016) used this database to investigate hail initiation events in pre-frontal environments.

\subsection{Storm and hail swath detections}


Terms like storm path, hail streak, hail swath, storm- and hail initiation are used throughout this manuscript. These elements have already been defined and described in the literature, but a short introduction is provided here.

In radar data studies, storm initiation is often defined as the first detection of a radar reflectivity signal exceeding 30 - 35 dBZ (e.g. Dixon and Wiener, 1993; Johnson et al., 1998; Roberts and Rutledge, 2003; Mecikalski and Bedka, 2006). The same definition is used in this study, since TRT runs with a minimum detection threshold of $35 \mathrm{dBZ}$. However, storm life cycle usually begins before the first hydrometeors are detectable by radars (cumulus humilis, cumulus mediocris; e.g. Stull, 1985). For example, several studies have demonstrated that satellite data can provide information about significant storm development some tens of minutes prior to the radar (e.g. Knight and Miller, 1993; Roberts and Rutledge, 2003; Mecikalski et al., 2008, 2010, 2013; Nisi et al., 2014). Since satellite datasets are not included in the study, the very early stages of convective storms are not included in the analysis.

To minimize TRT misdetections, only storms with a minimum duration of 15 minutes were included in the analysis. Furthermore, new storms that originate from splitting processes (Bluestein et al., 1990) are not considered in the storm initiation analysis. Finally, to avoid areas where beam widening effects become large (e.g. Cintineo et al., 2012), the maximum range between the location of the storm and the radar site is set to $160 \mathrm{~km}$. With these restrictions, approximately 191'000 out of 1.1 million detected storms are included in the 15-year period of analysis. Of these, approximately $31^{\prime} 000$ are hail storms

Hail swaths (HSWs) are the "hail footprints" of storms. Their geometric form is usually narrow and elongated (e.g. Figure 4). Hail swaths typically vary in width from a few hundred meters to a few kilometres, and in length from a few kilometres to several tens of kilometres (Foote and Knight, 1977; Knight and Knight, 2001). A HSW can contain several hail streaks (HST, Figure 4). In this study, a HST is detected when a thunderstorm shows $\mathrm{POH}$ values exceeding $80 \%$ over an area of at least $5 \mathrm{~km}^{2}$. The first time step at which these criteria are met is considered as the HST initiation time. During its life cycle, a storm can produce several non-contiguous HSTs. In this study, two HSTs must show a minimum time difference of 15 minutes to be considered independent. A sensitivity 
analyses (not presented in this manuscript) showed that lower thresholds lead to noisy datasets.

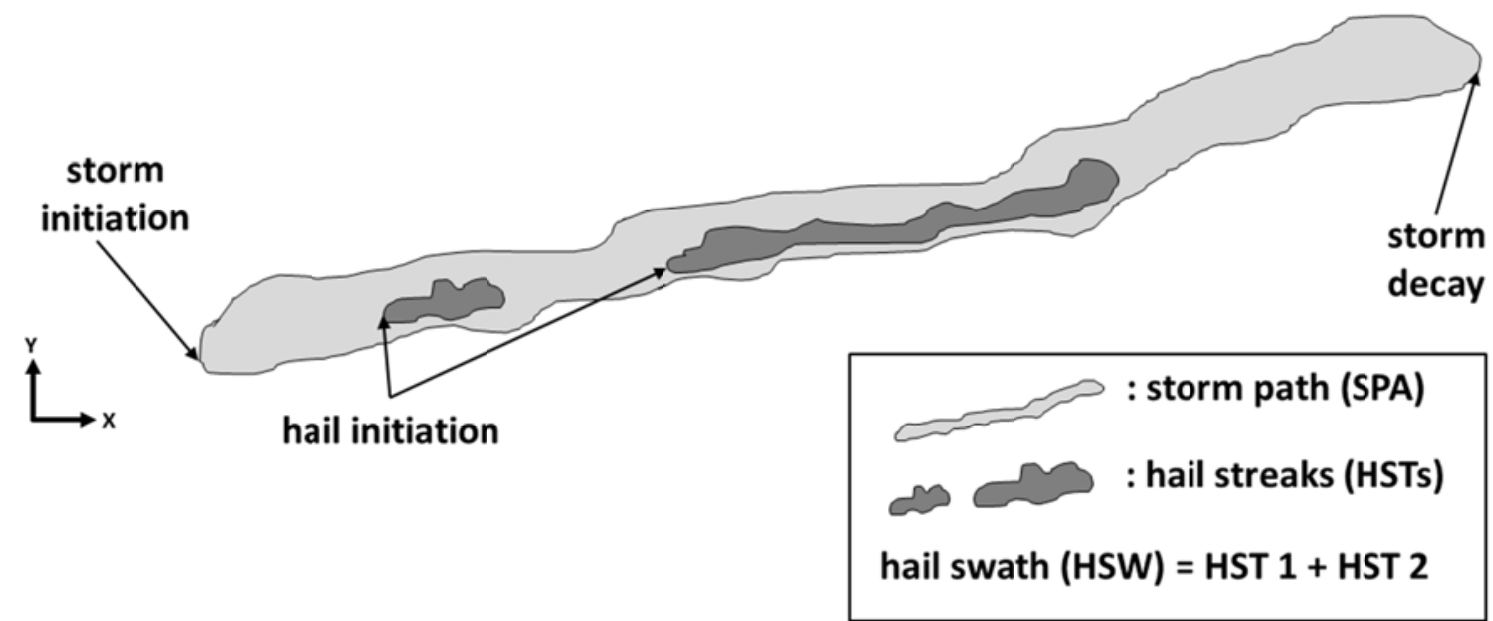

Figure 4: Illustration of some concepts used in this manuscript. Adapted from Changnon (1970).

Storms are divided into two main classes:

1. ordinary storms: thunderstorms with $\mathrm{POH}<80 \%$ during the entire storm life cycle;

2. hail storms: thunderstorms with a HSW of at least $5 \mathrm{~km}^{2}$ with $\mathrm{POH} \geq 80 \%$.

Together, these two classes contain $100 \%$ of the storms selected for this study. This means that each storm taken into account belongs to either the ordinary storm class or to the hail storms class. Hail information from MESHS is then used to further divide storms into two subclasses according to hail size:

2a. hail storms $\geq 2 \mathrm{~cm}$ : thunderstorms with a $\mathrm{HSW}$ of at least $5 \mathrm{~km}^{2}$ with $\mathrm{POH} \geq$ $80 \%$ and at least $5 \mathrm{~km}^{2}$ with MESHS $\geq 2 \mathrm{~cm}$;

2b. hail storms $\geq 4 \mathrm{~cm}$ : thunderstorms with a HSW of at least $5 \mathrm{~km}^{2}$ with $\mathrm{POH} \geq$ $80 \%$ and at least $5 \mathrm{~km}^{2}$ with MESHS $\geq 4 \mathrm{~cm}$. 
Note that the hail storm $\geq 2 \mathrm{~cm}$ class contains the storms of the hail storm $\geq 4 \mathrm{~cm}$ class.

There is no direct relationship between $\mathrm{POH} \geq 80 \%$ and MESHS $\geq 2$ and $\geq 4 \mathrm{~cm}$, since POH and MESHS are two different algorithms. MESHS classes are more discriminant and contain only the most severe hail storms. The $\mathrm{POH} \geq 80 \%$ class also contains hail storms with hailstones smaller than $2 \mathrm{~cm}$.

Finally, storms can also be described by their explosivity. This term is often used to highlight the rapid deepening of an extratropical cyclone (e.g. Sanders, 1986). In the literature, it is also often used to describe rapid thunderstorm development or intensification (e.g. Wicker and Wilhelmson, 1995; Mecikalski et al., 2013), typically when a storm develops in a very unstable environment but with a strong capping layer (e.g. McGinley, 1986). In this study, the time difference between storm initiation and HSW initiation is used as a proxy for storm explosivity (Figure 13, d). The shorter this time difference is, the more explosive the storm is.

In the diurnal cycle analysis, all times are given in UTC (Universal Time Coordinated). In Switzerland, the Central European Summer Time (CEST) is used and corresponds to UTC +2 hours.

\section{Results and discussion}

The thunderstorm database described in the previous section is used to calculate hail storm statistics. First, the frequency of different types of storms, including their spatial distribution and annual frequency anomalies, are presented. The focus is on storm- and HST initiation associated with different WTs. Second, the characteristics of HSTs are discussed.

\subsection{Storm type occurrence and temporal variability}

The annual number of storms decreases with increasing hail threshold (Figure 5). In total, an average of more than 12'700 storms are detected each year (standard deviation $=2200$; hereafter STD). Of these, slightly more than 10'000 are ordinary storms $(\mathrm{STD}=2500)$ and approximately $2 ' 100$ are hail storms with $\mathrm{POH} \geq 80 \%(\mathrm{STD}=770)$. These again contain, on average, approximately 1'200 hail storms with MESHS $\geq 2 \mathrm{~cm}(\mathrm{STD}=450)$ and 460 hail storms with MESHS $\geq 4 \mathrm{~cm}(\mathrm{STD}=180)$. In the 15 -year period, the number 
of ordinary storms increased slightly (by $3.3 \%$ per year). This is a tendency and not a trend. Trend analysis in general, including thunderstorm frequency, requires high spatial coverage and long-term datasets. Since the time span of our dataset is limited, trends cannot be calculated.

To capture the year-to-year variability, standardized annual storm number anomalies (Wilks, 2006; Nisi et al., 2016) are calculated for all ordinary thunderstorms and hail storms. The ordinary thunderstorm anomalies are within the interval \pm 0.7 STD for 12 out of 15 years (Figure 6). During three years $(2003,2014,2016)$, the anomalies exceed $|1.5|$ STD. The anomalies for all hail storm classes show less year-to-year variability: 11 years show very similar anomalies and only 4 years show strong positive anomalies. We can distinguish two types of convective seasons: seasons with an above average hail frequency, and others with an average number of hail storms. The number of hail storms in "normal" seasons is almost constant. There is an apparent decrease in the number of hail storms due to the fact that there have been no seasons with an above average hail frequency since 2009 .

Yearly differences are a first indication that the overall hail storm frequency may be driven by large-scale circulation patterns (e.g. Giaiotti et al., 2003). An analysis of long series of lightning data demonstrated, for example, that the North Atlantic Oscillation (hereafter NAO) has a significant impact on the occurrence of convection over different areas of Europe (Piper and Kunz, 2017). Furthermore, Riemann-Campe et al. (2010) found that CAPE and CIN are correlated with the NOA in the extra-tropical Northern Hemisphere. Negative phases of NAO are characterized by frequent troughs moving toward Central Europe; the related quasi-geostrophic forcing favours the initiation of convection. During positive NAO, the jet stream shifts toward northern Europe and anticyclonic conditions, and therefore stronger convective inhibition, persist over central and southern Europe. Piper and Kunz (2017) demonstrated that the relationship between NAO phases and thunderstorm frequency is not homogeneous over the whole Alpine area. Orographic forcing and local Alpine and sub-Alpine climates also affect the occurrence of thunderstorms (e.g. Nisi et al., 2016). 
High hail storm frequencies are not related to the general increase in the number of convective storms. On the contrary, a convective season with a large number of storms does not typically coincide with a positive hail storm anomaly. For example, the highest number of convective storms was detected in 2014 (Figure 5, a), but most of them were ordinary, non-hail producing thunderstorms and the hail storm number anomalies for this year were negative.

On average, the percentage of ordinary storms is four times larger $(\sim 83 \%)$ than the percentace of hailstorms. Overall, more than 8 in 10 thunderstorms are ordinary storms and only a small number $(\sim 4 \%)$ produce very large $(\geq 4 \mathrm{~cm})$ hailstones (Figures 7$)$. The yearly hail storms anomaly is not directly related to the yearly fraction of hail storms. The former corresponds to the difference between the number of hail storms in a particular year and the multi-year average number of hail storms. The latter corresponds to the fraction of hail storms in a particular year. Three out of the four years with a positive hail storm frequency anomaly $(2006,2008,2009)$ show a slightly above average fraction of hail storms.

In contrast, 2003 had a higher fraction of hail storms than any other year (Figure 7). A heat wave in Europe during June, July and August was linked to very high average temperatures and dry conditions (e.g. Schär and Jendritzky, 2004). In fact, the summer of 2003 was one of the three driest warm seasons since 1500 (Casty et al., 2005). This led to a below average total number of thunderstorms, but the highest percentage of hail storms $(\sim 40 \%)$ compared to the 15-year mean $(\sim 17 \%)$ (Figure 7$)$. The northward shift of the polar jet and persistent anticyclonic conditions caused a decrease in baroclinic activity over Central Europe (e.g. Feudale and Shukla, 2011). As a result, there were fewer frontal systems passing over Europe that could release potential instability over the Alps during that summer. The thunderstorms that did occur over Switzerland were on average more severe in terms of hail compared to thunderstorms in other years. 
4.5). North of the Alps, a second hail storm frequency maximum is located over the Jura Mountains, a secondary mountain ridge in northwestern Switzerland. A third strong hail storm maximum is evident in the southern Swiss Alps. In the case of southwesterly prefrontal flow, a weather regime that commonly produces hail in the southern Alps (Nisi et al., 2016), this area is often subject to strong orographic forcing, moisture convergence zones, and strong wind shear (e.g. Panziera et al., 2015). This results in multi-cell clusters and hail storms in pre-frontal and frontal situations (e.g. Schemm et al., 2016; Cacciamani et al., 1995).

The hail frequency minimum in the heart of the Alps (Nisi et al., 2016) is in agreement with a minimum in the storm track frequency in this area (Figure 8, a0). Few thunderstorms occur above and in proximity to the main Alpine ridge. These storms are short-lived and most are quasi-stationary (not shown). The combination of lower moisture and high friction hinders the formation and organisation of storms in the heart of the Alps (van Delden, 2001; Nisi et al., 2014, 2016). Because of lower temperatures near the surface in the mountains, graupel is common during convective precipitation, but large hail is rare. This is confirmed by HSW frequencies below 1 for both MESHS $\geq 2 \mathrm{~cm}$ and MESHS $\geq 4 \mathrm{~cm}$ storms.

The challenges of using radar-based approaches over complex terrain are discussed in Nisi et al. (2016). There is one issue related to radar technology that affects our results. There was a sensitivity issue with the previous generation radar system on La Dôle, which covers part of western France (area highlighted in red in Figure 8, b0). First, there is a cone with low frequencies to the southwest of the radar (Figure 8, a0) that is caused by shielding due to an obstacle located close to the radar. Second, because of a lower radar sensitivity, the storm frequencies over France are likely underestimated. According to Vinet (2001), the southern French foothills are a hail-prone area; an underestimation is therefore likely, particularly for ordinary storms, where lower radar reflectivities are involved. An underestimation of the number of hail storm tracks and HSTs is also present but less evident. Both issues were present in the former generation La Dôle radar data $(2002$ - 2011) and solved in the current generation (Germann et al., 2015). 

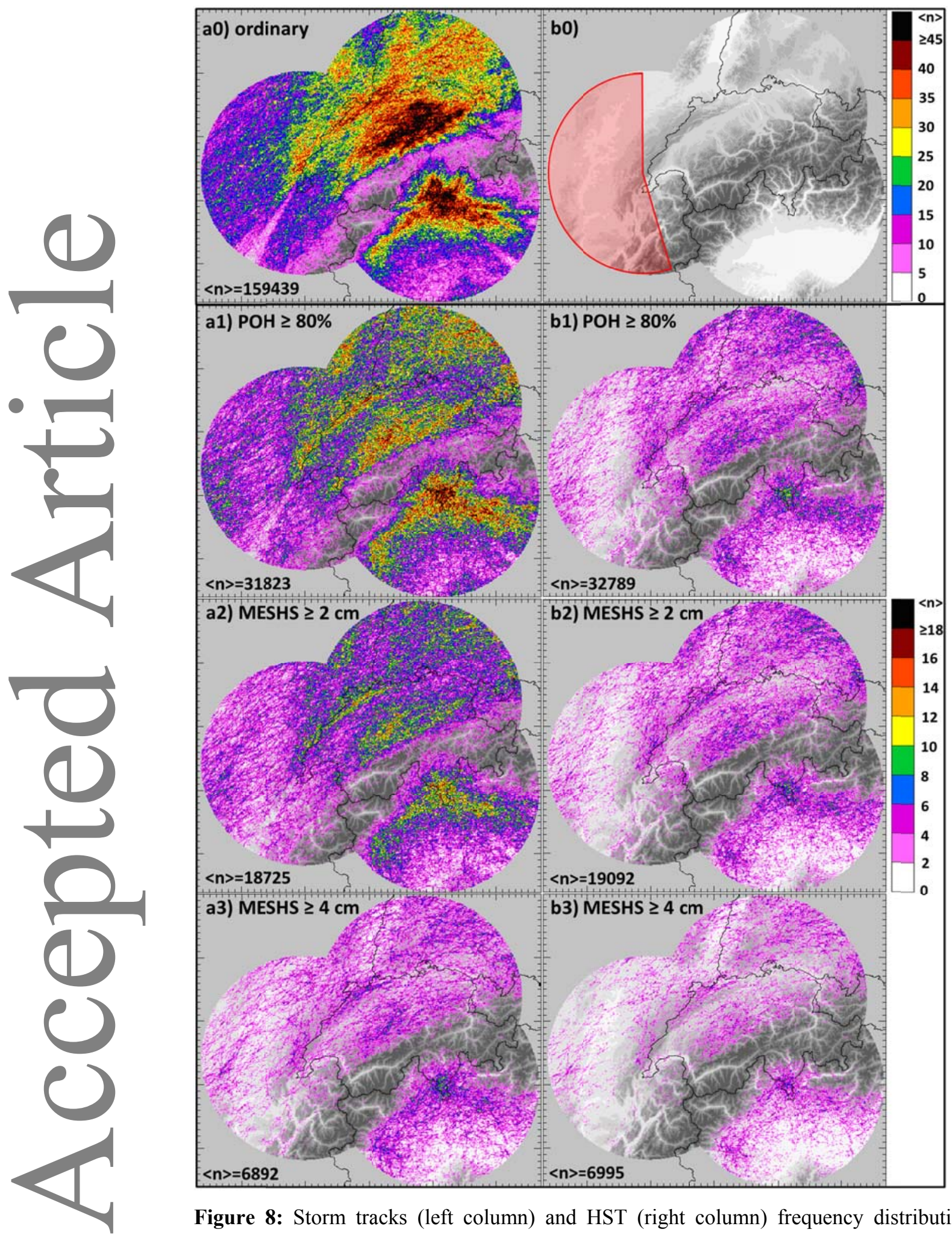

Figure 8: Storm tracks (left column) and HST (right column) frequency distribution. Storms are selected according to different thresholds: ordinary storms (no hail, a0), $\mathrm{POH} \geq 80 \%$ (a1, b1), MESHS $\geq 2 \mathrm{~cm}(\mathrm{a} 2, \mathrm{~b} 2)$ and MESHS $\geq 4 \mathrm{~cm}(\mathrm{a} 3, \mathrm{~b} 3) .<\mathrm{n}>$ is the number of individual tracks considered. The 
area highlighted in red in panel b0 indicates the location of sensitivity issues with La Dôle radar during the $3^{\text {rd }}$ radar generation, $2002-2011$.

\subsection{Hail streak occurrence}

We will next discuss the behaviour of individual hail swaths within storms. The large majority of storms produce one HST. Only a small percentage $(<4 \%)$ of all hail storms produces 2 or more independent (non-consecutive) HSTs (Table 1). This percentage decreases with increasing hail threshold. These results differ from those found over the U.S., where more than $20 \%$ of the hail storms produced 4 or more HSTs (Changnon, 1970). Due to differences in the observation systems, the spatial and temporal resolution of the observations, and the methodologies (manual vs. automatic algorithms), it is difficult to say if the different fraction of pulsating storms is the result of methodological or physical differences.

Split storms (e.g. Klemp and Wilhelmson, 1978; Schlesinger, 1980; Rotunno and Klemp, 1982) are considered separately. Two HSTs resulting from a splitting process are considered as independent. The percentage of splitting hail storms is high (32\%, Table 1$)$. The probability of a storm splitting increases with increasing storm severity. The majority of storm splits ( $\sim 61 \%)$ occur at an early stage in the life cycle of a storm. In ideal cases, storm splits result in a right-moving and a left-moving updraft. The right-moving storms are usually stronger and longer-lasting (e.g. Klemp and Wilhelmson, 1978; Bluestein et al., 1990). In Switzerland, severe storms are divided equally into right- and left-moving storms (Schmid et al., 1993; Schiesser et al., 1995). Orographic effects on the local airflow and typically weaker wind shear compared to U.S. storms prevent the predominance of rightmoving storms (Huntrieser et al., 1997). In $\sim 84 \%$ of the cases, only one of the two storms produced an HST after a split process.

\begin{tabular}{|c|c|c|c|c|c|}
\hline Storm type & $\begin{array}{l}\text { Number } \\
\text { of storms }\end{array}$ & $\begin{array}{l}\text { Storm } \\
\text { splits } \\
\text { (in \%) }\end{array}$ & $\begin{array}{c}\text { Storms } \\
\text { with } \\
1 \text { HST } \\
\text { (in \%) }\end{array}$ & $\begin{array}{c}\text { Storms } \\
\text { with } \\
2 \text { HSTs } \\
\text { (in \%) }\end{array}$ & $\begin{array}{c}\text { Storms } \\
\text { with } \\
\geq 3 \text { HSTs } \\
\text { (in \%) }\end{array}$ \\
\hline Ordinary & 159439 & 17 & - & - & - \\
\hline $\mathrm{POH} \geq 80 \%$ & 31823 & 32 & 96.9 & 3.0 & 0.1 \\
\hline
\end{tabular}




\begin{tabular}{|l|l|l|lll|}
\hline MESHS $\geq 2 \mathbf{c m}$ & 18725 & 41 & 97.9 & 2.0 & 0.1 \\
MESHS $\geq \mathbf{4 c m}$ & 6892 & 48 & 98.5 & 1.4 & 0.1 \\
\hline
\end{tabular}

Table 1: Total number of storms (2002 - 2016), percentage of storm splits, and percentage of storms characterized by 1,2 or more independent HSTs.

HST distribution and occurrence depend on large-scale circulation patterns. In Figure 9, all HSTs are considered independent, regardless of whether their initiation occurred inside or outside of the selected radar sub-domain $(\mathrm{r}=160 \mathrm{~km})$. HST frequencies are highest during weather situations characterized by westerly and south-westerly flow. These two WTs contain $36 \%$ and $26 \%$ of all HWSs, respectively. During westerly flow, the frequency maximum is located in northwestern Switzerland along the Jura Mountain ridge. During south-westerly flow, frequency maxima are located in the foothills south of the Alps. In all other flow regimes, HSWs are less frequent: each WT contains a HSW fraction between $1 \%$ and $12 \%$. However, HSTs exhibit frequency maxima over specific locations. For example, in several WTs (e.g. W, SW and S), the HSTs are "channeled" parallel to the western slope of the Jura Mountains in western France. The spatial distribution of HSTs indicates that the orography is not only able to trigger convection, but also affects the propagation of severe storms. 


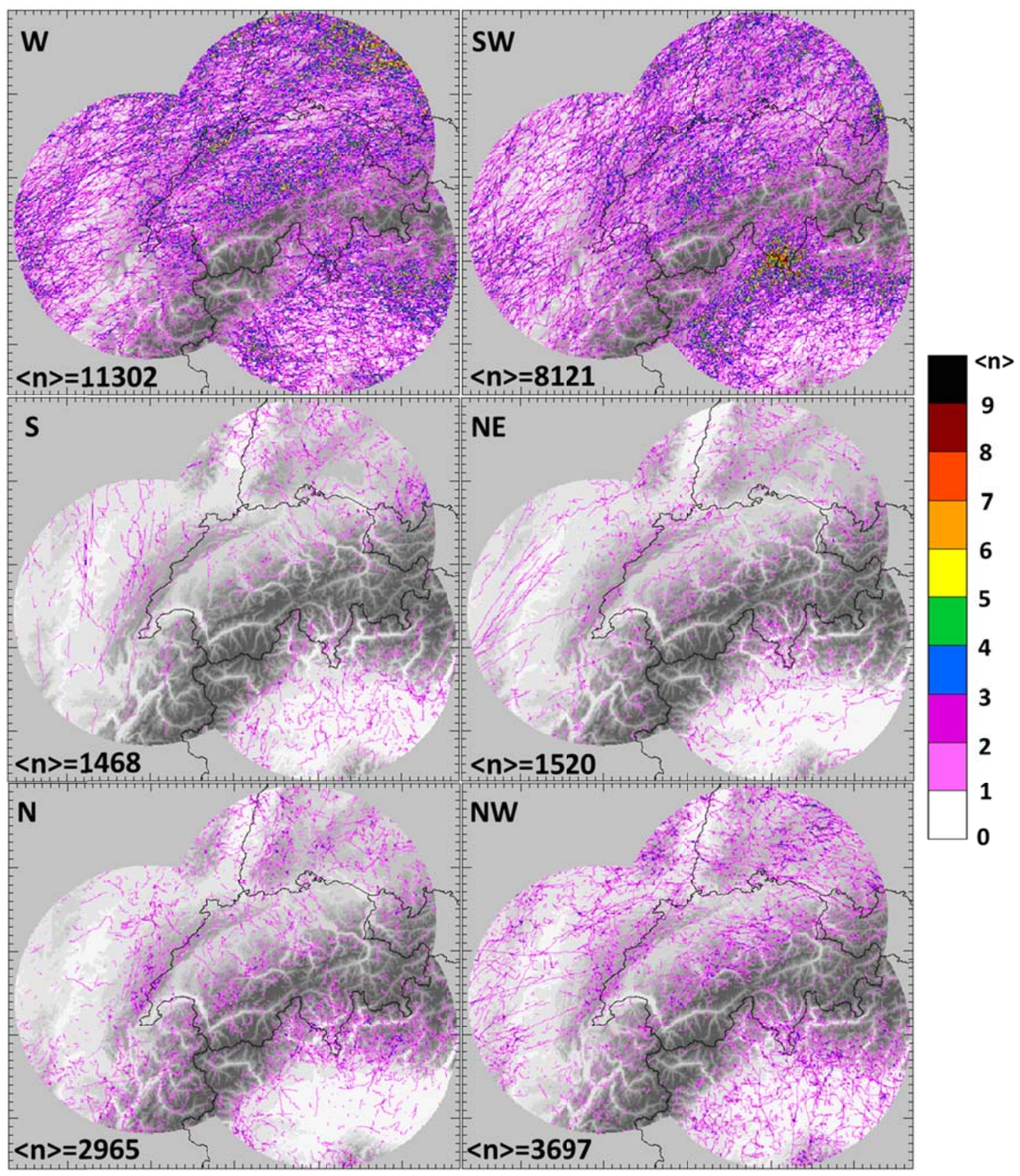

Figure 9: HST occurrence for different WTs. HSTs are selected using a threshold of $\mathrm{POH}=80 \%$. Only the six WTs with a number of hail storms greater than 1'000 are shown.

\subsection{Storm and hail streak initiation}

The role of complex terrain in triggering convection is widely acknowledged (e.g. Huntrieser et al., 1997; Davolio et al., 2009; Weckwerth et al., 2011, Nisi et al., 2014, 
Trefalt et al., submitted). This study investigates not only thunderstorm initiation, but also HST initiation (Figure 10).

Initiation locations are strongly correlated with the orography. Ordinary thunderstorms (Figure 10, a0) form frequently along the northern and southern foothills of the Alps, along the Jura Mountains, over the Black Forest in southern Germany, and in the Swabian Jura. Initiations in the heart of the Alps are rare. As described in Section 3.4, initiations are identified using a relatively weak radar reflectivity threshold of $35 \mathrm{dBZ}$. For this reason, the radar issues (shielding, underestimation) described in Section 4.1 in Nisi et al. (2016) may have an influence on thunderstorm detection in the inner Alps (e.g. Figure 10, $\mathrm{a} 0)$.

There are no evident differences between the storm initiation locations and HST initiation locations (Figure 10, a1-a3, b1-b3). Hail storms and HWS initiation maxima over the foothills are in close proximity. This is an indication that hail storms usually have an explosive development and/or are slow-moving. 

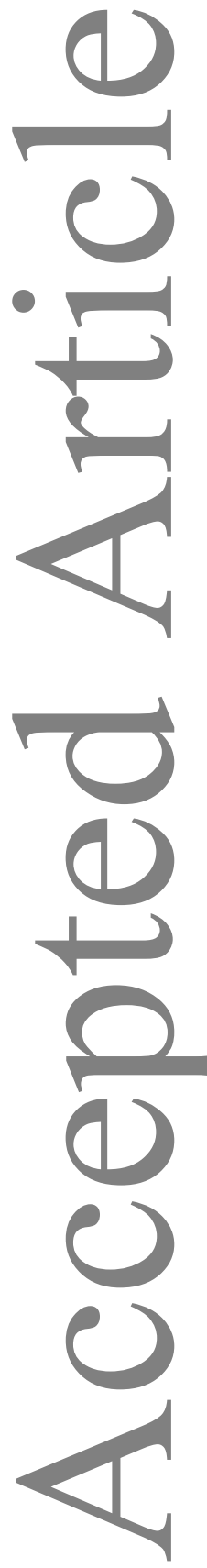

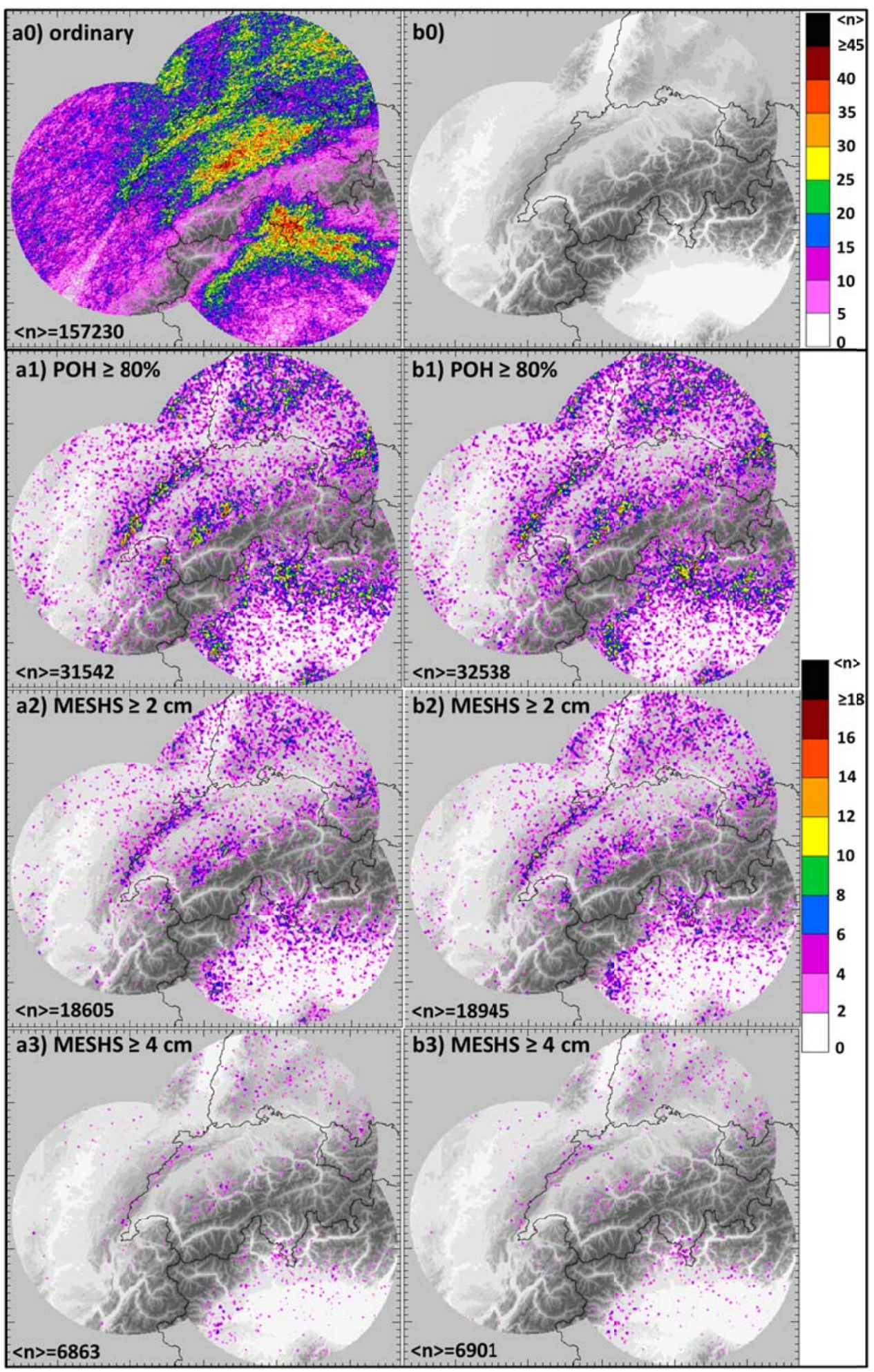

Figure 10: Storm- (left column) and HST-initiation (right column) frequency distribution. Storms are selected according to different thresholds: ordinary storms (no hail), $\mathrm{POH} \geq 80 \%$, MESHS $\geq 2 \mathrm{~cm}$ and MESHS $\geq 4 \mathrm{~cm}$. 
The initiation of storms with MESHS $\geq 4 \mathrm{~cm}$ are more homogenously distributed, especially south of the Alps. Such hail sizes occur in well-organized storms like supercells. The occurrence of supercells depends largely on the environmental wind shear (e.g. Markowski and Richardson, 2010). Mountains interfere with the airflow, reducing the possibility of developing an organized and persistent structure (e.g. Schiesser et al., 1995). In northern Switzerland, HST initiations are predominantly located along the northern slope of the Alps and in the Jura Mountains. There, especially in the case of prefrontal environments, an overall greater bulk wind shear (Schemm et al., 2016) can promote severe storms even if complex terrain affects the low-level mesocyclone structure.

Hail storm initiations can be separated according to large-scale circulation patterns (Figure 11). During four WTs (SW, W, NW, N), initiation frequency maxima are located over hilly terrain and a more homogeneous initiation distribution is found over plain areas. During northeasterly and southerly flow, the frequency maxima are less pronounced. During northeasterly and southerly flow regimes, a synoptic-scale low pressure system is usually not far from the Alps (Weusthoff, 2011; Rohrer, 2013). The combination of abundant low-level moisture, high instability and wind shear is favorable for storm initiation even without the orographic forcing. Previously studies (e.g. Kottmeier et al., 2008; Hagen et al, 2011) have demonstrated that, depending on the flow direction and air mass stability, the interaction with orography can be crucial for convection initiation. Presumably, WTs showing large frequency maxima over the foothills contain a higher fraction of air mass convection caused by surface fluxes and thermally driven wind systems (differential heating). 


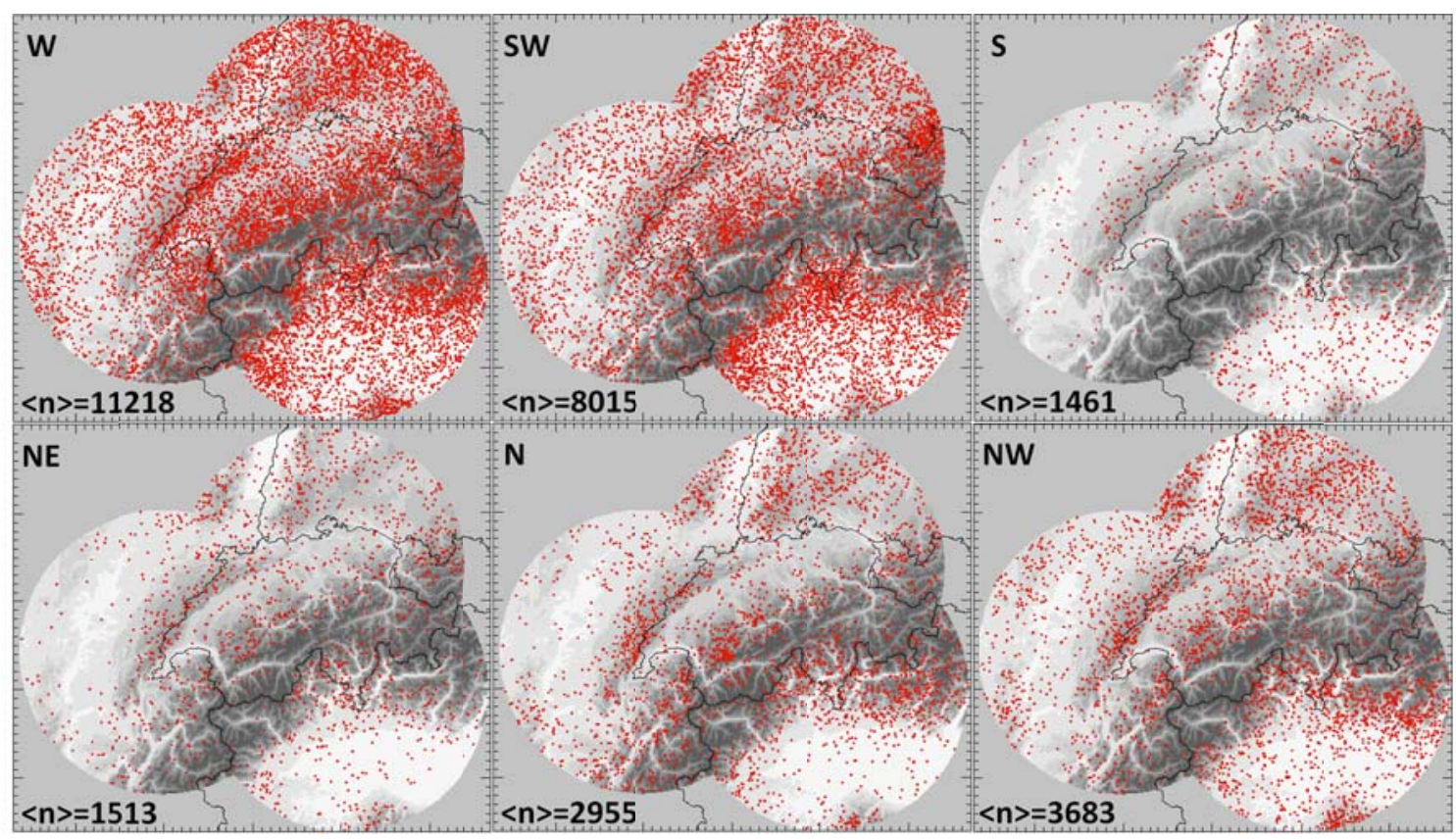

Figure 11: Spatial distribution of hail storm initiation for different WTs. Hail storms are selected using a threshold of $\mathrm{POH}=80 \%$. Only the six WTs that show a number of storms greater than 1000 are shown.

\subsection{Hail storm explosivity, duration and path length.}

Spatial and temporal characteristics of SPAs and HSTs provide information about storm stationarity, longevity and explosivity. In Figure 12, path lengths and durations as well as spatial and temporal distances between storm- and hail-initiation are analysed for different hail thresholds. With increasing hail severity, both SPAs and HSTs have a greater spatial and temporal extent (the median length of the MESHS $\geq 2 \mathrm{~cm}$ sample and the MESHS $\geq 4$ cm sample are $30 \%$ and $76 \%$ longer, respectively, than the $\mathrm{POH} \geq 80 \%$ sample). The increase in HST size is greater than that of an entire SPA in both space and time.

The stronger the updraft, the higher the capability of the storm to produce persistent hail cores and large hailstones. The normalization of HST length and duration to the entire storm life cycle (boxplots c and d in Figure 13) shows a strong increase with increasing hail storm severity. Severe HSTs are more persistent in space and time. On average, HSTs in $\mathrm{POH} \geq 80 \%$ storms cover $\sim 19 \%$ of the total distance of storm paths and last for $36 \%$ of the total duration of storm life cycles. For MESHS $\geq 2 \mathrm{~cm}$ storms, we obtained $37 \%$ (distance) and 47\% (duration), and 49\% (distance) and 62\% (duration) for MESHS $\geq 4 \mathrm{~cm}$ storms. 

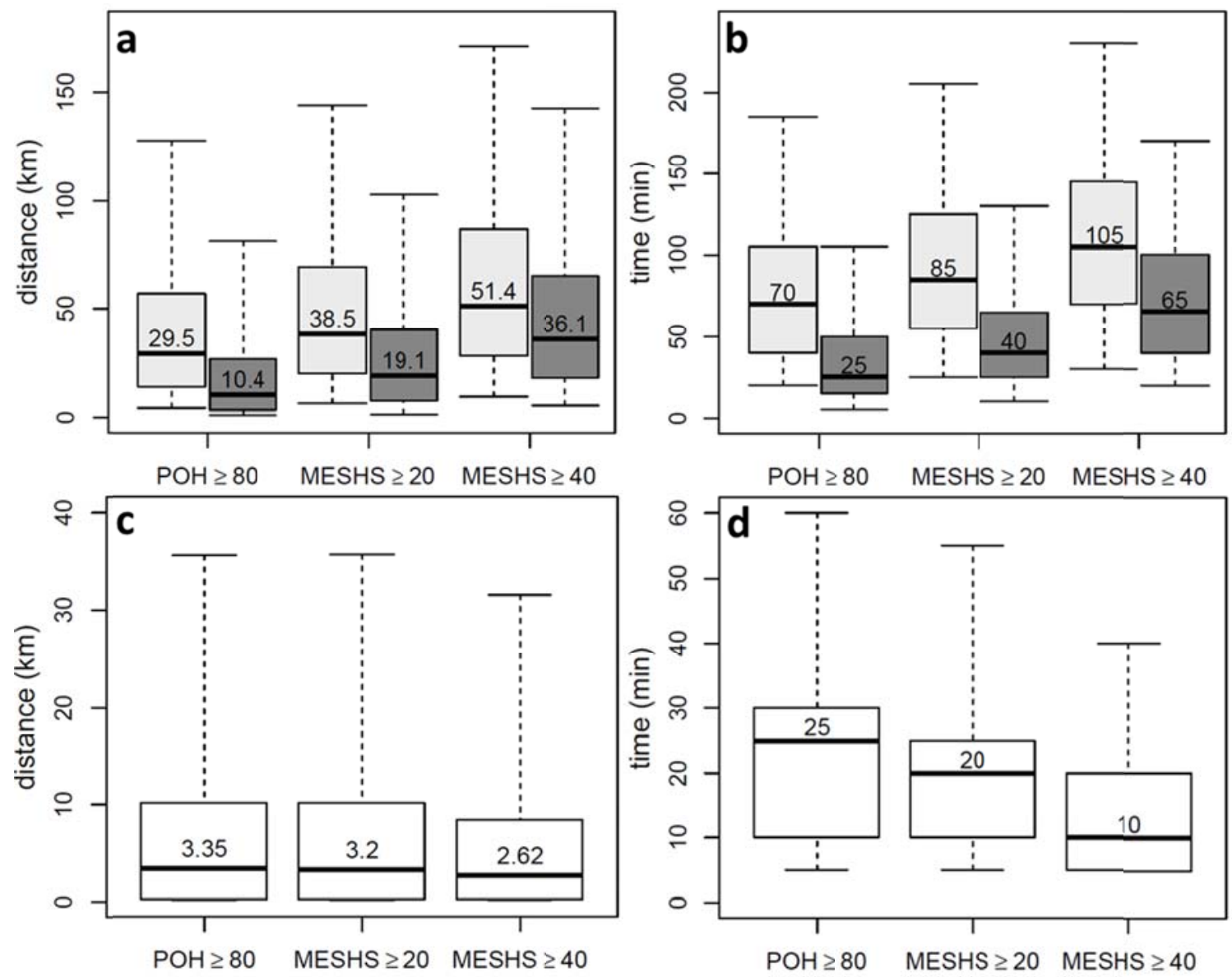

Figure 12: The panel figure shows hail storm trajectories and HST lengths (a), duration (b), and the spatial (c) and temporal (d) distance between storm initiation and hail initiation for three different POH and MESHS thresholds. Light grey boxes show entire storm trajectories; dark grey boxes show only the HSTs. Only SPAs that are entirely in the research domain are considered: 30'523 storms with $\mathrm{POH} \geq 80 \%, 18^{\prime} 005$ storms with MESHS $\geq 2 \mathrm{~cm}$, and 6'797 storms with MESHS $\geq 4 \mathrm{~cm}$.

The time lag between storm- and HST-initiation is taken as a proxy for storm explosivity. There is a decrease in both the spatial and temporal distance between initiation and hail formation (Figure 12c and 12d) with increasing storm severity. The median values, the $75^{\text {th }}$ percentile of the initialization distances, and the relative decrease are small. This indicates that the large majority of storms are quasi-stationary during their initial stages. Median values of the initiation time lag show a clear decrease: on average, a MESHS $\geq 4$ $\mathrm{cm}$ storm starts producing hail 10 minutes after the first radar detection. The clear decrease in the median, $75^{\text {th }}$, and $95^{\text {th }}$ percentile is an indication that the more intense a storm is, the more rapidly it develops. 
Spatial and temporal differences between initiations are normalized with the life spans of the storms (boxplots a and b in Figure 13). With increasing hail threshold, a decrease in both normalized spatial and temporal hail initialization differences is found. This decrease is stronger in time $(\mathrm{POH} \geq 80 \% \rightarrow 70 \%$, MESHS $\geq 2 \mathrm{~cm} \rightarrow 49 \%$, MESHS $\geq 4 \mathrm{~cm} \rightarrow$ $36 \%$ ) than in space $(\mathrm{POH} \geq 80 \% \rightarrow 11 \%$, MESHS $\geq 2 \mathrm{~cm} \rightarrow 8 \%$, MESHS $\geq 4 \mathrm{~cm} \rightarrow 5 \%$ ). Smaller spatial and temporal differences between storm and hail initializations indicate that hail storms are often quasi-stationary during their initial stages, and are characterized by rapid intensification.

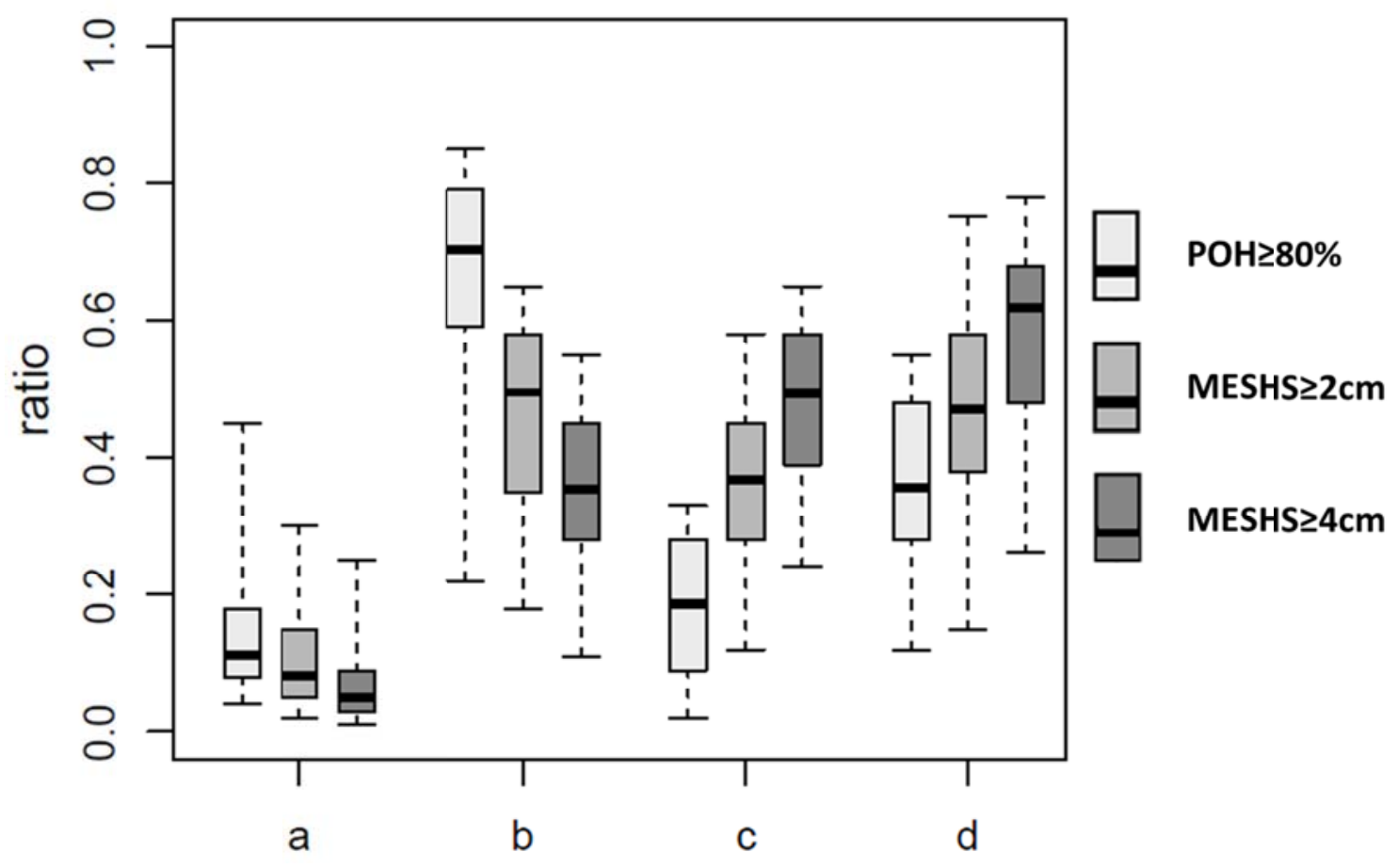

Figure 13: Normalized distance (a) and time span (b) between storm formation and hail initiation, HST length (c), and duration (d). Distances and durations are normalized with entire storm trajectory lengths and durations, respectively.

Figure 14 shows hail storm characteristics for different weather regimes. During westerly, south-westerly, and southerly flows, SPAs and HSTs last longest and cover the largest distances. This may be because a greater fraction of storms developed in pre-frontal and frontal environments with higher wind shear and steering winds. In general, differences in HST lengths among the WTs are small. Differences in the average storm duration are also small. WTs that are more commonly influenced by synoptic forcing (e.g. W, SW, S) show a slightly higher average storm duration. Average HST duration is almost constant for the majority of WTs (Figure 14b). Despite the chaotic nature of convective processes and the 
large number of parameters and dependences involved, it seems that the duration of HWSs is intrinsically limited by the typical life cycle of thunderstorms. Although multicellular clusters may persist for hours, individual storms have a typical life cycle of about $30-60$ minutes (Markowski and Richardson, 2010). Thus, the duration of HWSs is also limited.

The separation of the spatio-temporal differences between storm initiation and hail initiation according to weather regimes does show clear differences. Greater spatial differences for W, SW and S WTs, but constant temporal differences among all WTs, indicate that the intensity of wind shear may play a role (Figure 14c). During these weather regimes, storms move more rapidly than usual and therefore cover larger distances. Differences in the storm intensifications are small. This indicates that almost no relationship exists between storm explosivity and the large-scale weather regime.
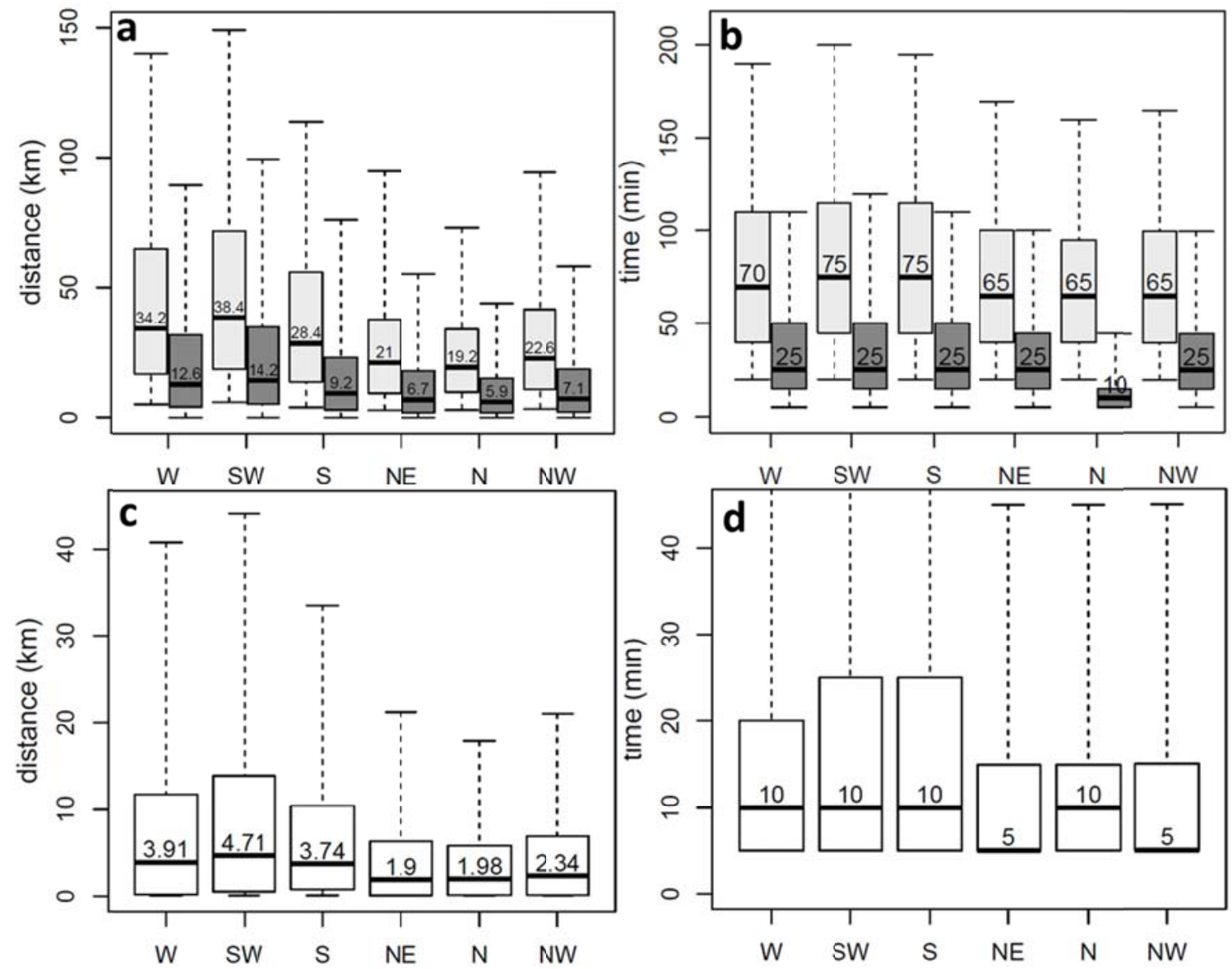

Figure 14: The figure shows storm trajectories and HST lengths (a), duration (b), and the spatial (c) and temporal (d) distance between storm initiation and hail initiation for three different WTs. Hail storms are selected with a threshold of $\mathrm{POH}=80 \%$. Only the six WTs with more than 1000 hail storms are shown. Light grey boxes correspond to entire storm trajectories; dark grey boxes show only the HST. 


\subsection{Yearly, monthly and diurnal cycle of storms and hail streaks}

In this section, the length (a), distance (b), and area (c) of the SPAs and HSTs are analysed at yearly, monthly (Figure 15) and diurnal (Figure 16) scales. For all three time scales, the distribution of spatio-temporal differences between thunderstorm and HST initiation shows no trends (not shown). There are no significant trends in SPA and HST lengths (Figure 15, a0). Yearly median lengths of both SPAs and HSTs follow a normal distribution, with the SPA yearly median length varying between 18 and $37 \mathrm{~km}$ and the HST median length varying between 6 and $21 \mathrm{~km}$. There are no significant trends in SPA and HST median duration (Figure 15, b0), but a significant increase in the average SPA and HST area is observed (Figure 15, c0). In summary, HST average areas are constant over the reviewed period, whereas the average SPA area increases.

Summer 2003, a particularly dry year, does not stand out in terms of SPA and HST length, duration, or average area. Despite frequent conditions favouring hail storms (see Section 4.1), SPAs and HSTs were not more extended or longer-lasting than the multi-year averages.

Monthly distributions reveal a significant seasonal cycle in all three parameters. A total of 31 '823 hail storms are considered (Table 1). The lowest number of storms (684) occur in April, whereas the highest (10'491) occur in July. A minimum in both SPA length and duration is found in June and July (Figure 15, a1 and b1). Larger values are found in April and September. The minimum is caused by a greater fraction of air mass convection occurring during the months with the highest solar radiation. These storms and the storms produced by differential heating and local convergences are usually quasi-stationary and hence produce short SPAs. Furthermore, the absence of wind shear and the subsequent expansion of the cool pool below the thunderstorm reduces the storm's life cycle (e.g. Markowski and Richardson, 2010). At both the beginning and the end of the warm season, air masses are usually less favourable for the development of thunderstorms. In these cases, additional forcing, e.g. frontal (e.g. Schemm et al., 2016), is needed. HSTs follow an opposite seasonal cycle compared to SPAs. The maximum HST extension and duration is found between June and August. While severe storms can persist for a long time in relatively cold air masses (April, May, September), results indicate that moist and warm environments are more favourable for long-living HSTs. 
There is a distinct diurnal cycle in the hourly SPA and HST parameters (Figure 16). In this analysis, the lowest number of hail storms is found between 06 and 08 UTC (373) and the highest number between 14 and 16 UTC (7’355). For SPA length and duration, a maximum is found in the morning hours (06 to 08 UTC), followed by a relatively rapid decrease during the late morning and early afternoon (08 to 12 UTC). Morning peaks are difficult to explain. Compared to the afternoon, storms are fewer but long-lasting. Air mass convection is less common in the morning because insufficient surface heating leads to greater stability. Because high wind shear is needed, local convergences produced by the interaction of mountain and valley breezes are unable to generate long-lasting storms with long SPAs. Thus, frontal triggering is the most likely reason for these morning peaks. The successive decrease of SPA length and duration is explained by the increase in air mass convection as the day progresses. A minimum in both SPA length and duration is found in the middle to late afternoon (12 to 16 UTC) when air mass convection dominates.

HST lengths and durations show a similar but less pronounced diurnal cycle (Figure 16a and 16b). When air mass convection dominates, HSTs tend to be shorter in time and space. Slightly lower HST values are found in the morning hours (04 to 08 UTC). The signal is not very clear, but a slight anti-correlation between SPA and HST average areas is found. 


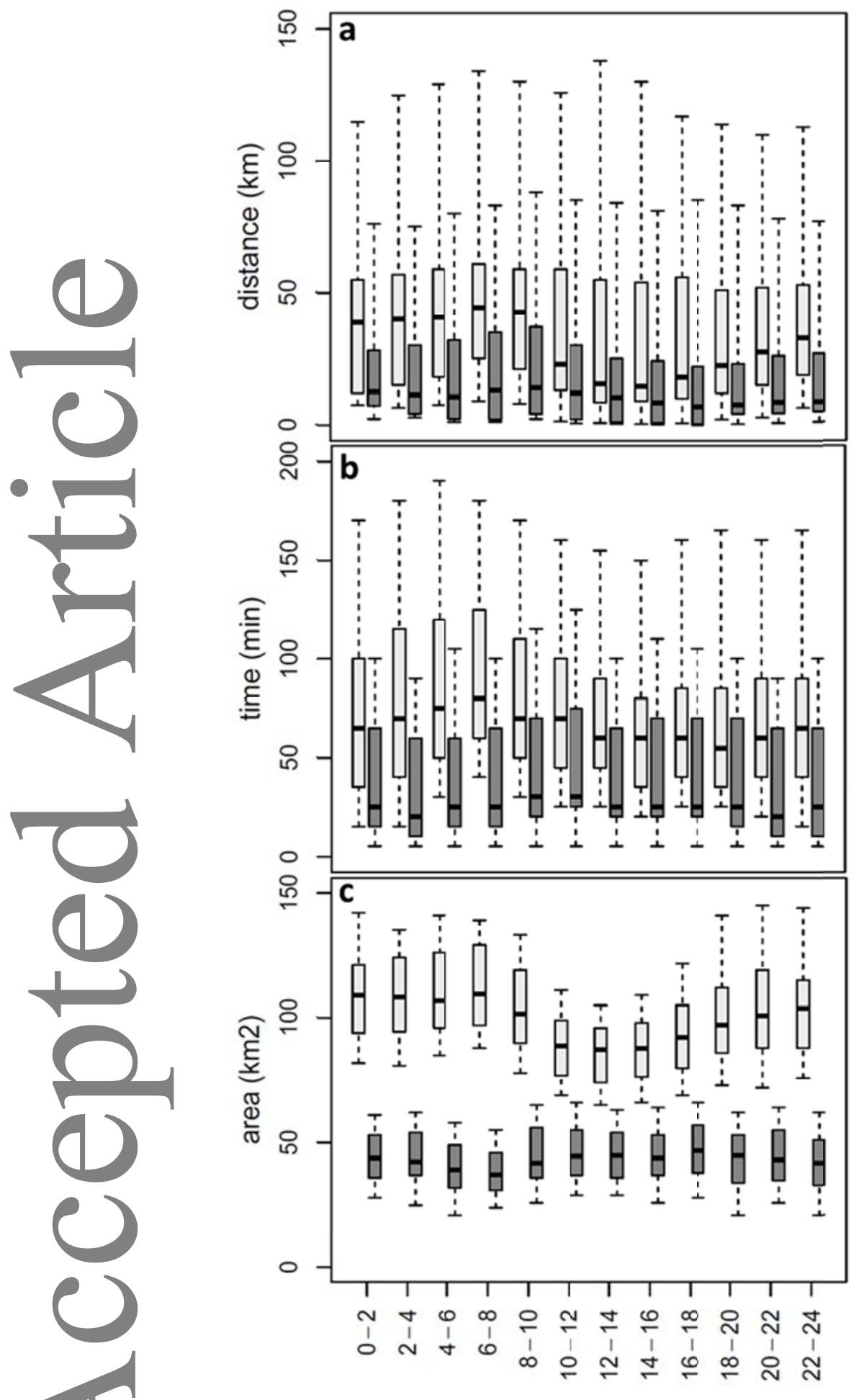

Figure 16: The figure shows the diurnal cycle of storm trajectories and HST lengths (a), duration (b) and average area. For visualization purposes, HST areas (c) are multiplied by 10. Light grey boxes correspond to entire storm trajectories, dark grey boxes to HSTs only. Local time $=\mathrm{UTC}+2$ hours. 


\section{Summary and conclusions}

A cell-based hail storm analysis based on 15 years of homogeneous volumetric radar data is presented. Radar-based hail detection algorithms (POH, MESHS), as well as a thunderstorm tracking algorithm (TRT), were used to reprocess Swiss radar data between April and September from 2002 - 2016, resulting in a unique database of more than 1.1 million storms.

In Switzerland and and adjacent regions the investigation domain more than 191'000 storms were analysed, of which more than 31'000 were hail-producing storms. Based on this dataset, information is provided on the spatial distributions, initiation locations, and trajectories of thunderstorms and hail streaks. The dependence of these characteristics on large-scale weather regimes is also discussed. Furthermore, radar data with a $1 \mathrm{~km}^{2}$ resolution were used to investigate the spatio-temporal characteristics of storm footprints.

Standardized anomalies of the yearly number of storms and hail swaths show that only few seasons have a hail storm frequency far above the average. A high hail occurrence in a particular year is not correlated with a higher number of convective storms, but is correlated with a greater fraction of hail storms (e.g. 2003). Other years that show a high number of convective storms (e.g. 2014) do not show positive hail anomalies. On average, ordinary thunderstorms account for about $83 \%$ of all convective storms, and hail storms about $17 \%$. Hail storms with hailstones $\geq 2 \mathrm{~cm}$ represent about $10 \%$ of the total, those with hailstones $\geq 4$ $\mathrm{cm}, 3 \%$. The hailstone size estimates are based on the MESHS radar product and hence subject to uncertainty.

Hail streak (HST) density maxima are found along both the southern and northern foothills in the pre-Alpine area. An additional maximum is found in the Jura Mountains in northwestern Switzerland. Very few HSTs are present along the Alpine main ridge; those that are present have a limited spatial and temporal extension. There is a good spatial correlation between ordinary thunderstorms and HST maxima: in general, areas that are often affected by hail are the same areas where thunderstorms are more frequent. However, some regional differences exist. For example, the hail storm maximum along the northern slope of the Alps is shifted southwestward compared to the location of the ordinary thunderstorm maximum.

The large majority of hail storms $(>96 \%)$ contain only a single HST. This percentage increases with storm severity. This is in agreement with generally longer lasting and more extended HSTs for MESHS $\geq 4 \mathrm{~cm}$ storms. Furthermore, the HST fraction of the total storm path (SPA) increases with increasing storm severity. Finally, the most severe storms show the 
most explosive evolution during the early stages of their life cycles. On average, only 10 minutes pass between the first storm detection by the radar and the first hail signal in storms producing $\geq 4 \mathrm{~cm}$ hailstones.

A strong dependence of HST occurrence on large-scale circulation patterns is found. During south-westerly and westerly weather regimes, HST frequencies are highest and storm tracks are long. However, HST duration and storm explosivity appear to be independent of circulation patterns. This indicates that more extended HSTs during south-westerly and westerly weather regimes are connected to stronger winds and therefore faster storm velocities. More than $62 \%$ of all HSTs occur during these two weather regimes.

The hail initiation maxima are located over the northern and southern foothills of the Alps and along the Jura Mountains and are typically displaced towards the southwest compared to the location of hail maxima. The low number of HST initiations in the heart of the Alps is consistent with the lower occurrence of lightning observed in this area (Nisi et al., 2014), and with the lower occurrence of overshooting tops (Punge et al., 2017). The dependence of hail storm occurrence and distribution on large-scale circulation is a very important result. Identifying the large-scale atmospheric drivers responsible for seasons with high hail frequency is of high practical value, not only for monthly and seasonal outlooks, but also for climate modelling. Large-scale atmospheric predictors are used to develop statistical models for reproducing and forecasting hail occurrence (e.g. Mohr et al., 2015, Madonna et al, 2017). Hail proxies derived from climate model simulations can then be used to estimate the evolution of regional hail occurrence in a changing climate (e.g. Mohr et al., 2015).

Yearly distributions of SPA and HST characteristics like length, duration and average area do not exhibit significant trends during the 15 -year time period. However, they do exhibit strong year-to-year variability, and distinct seasonal and diurnal cycles are found. The SPAs are shortest in space and time in June and July as a result of a larger fraction of quasi-stationary storms caused by air mass convection. In contrast, HSTs exhibit maximum HST spatiotemporal lengths in June and July. This indicates that stronger and persistent updrafts are produced in warmer and moister air masses.

The diurnal cycle is more pronounced for SPAs than for HSTs. SPA and HST minima are found in the afternoon hours, as this is when air mass and orographic convection produce stationary storms.

The results show nicely that radar-based approaches can be used for studies of thunderstorms and hail even in areas with complex orography. The combination of intelligent radar network 
design and sophisticated data processing makes radar (ground- and satellite based, e.g. Mroz et al., 2017) an excellent instrument for these type of studies. Climatological information of large storm trajectory datasets can be valuable for the nowcasting of severe storms, for climate monitoring, for the verification of NWP and for applications in the insurance sector. Future work will include a detailed analysis of the relationship between hail storm initiation/intensification/decay and orography. Given that convection initiation is very common in the Alpine area (e.g. Collier and Lilley, 1994; Huntrieser et al., 1997), and that orographic forcing is one of the main reasons for providing preferred thunderstorm pathways (e.g. Panziera et al, 2011), large storm datasets may be used in a probabilistic sense to provide thunderstorm severity nowcasts.

\section{Appendix 1}

\begin{tabular}{|c|c|c|}
\hline Parameter: & Explanation: & Units: \\
\hline \multicolumn{3}{|l|}{ Time and geolocation } \\
\hline 1. Storm-ID & $\begin{array}{l}\text { Each storm has a single ID for its whole life } \\
\text { cycle }\end{array}$ & - \\
\hline 2. FirstDetection & Date and time of storm initiation & - \\
\hline 3. LastDetection & Date and time of storm final decay & - \\
\hline 4. Centroid & $\begin{array}{l}\text { Geolocation of storm centroid (geodetic } \\
\text { coordinates) for each } 5 \text {-minute step for the } \\
\text { entire storm life cycle }\end{array}$ & {$\left[{ }^{\circ}\right]$} \\
\hline 5. Border & $\begin{array}{l}\text { Geolocation of storm border (geodetic } \\
\text { coordinates) for each } 5 \text {-minute step for the } \\
\text { entire storm life cycle }\end{array}$ & {$\left[{ }^{\circ}\right]$} \\
\hline \multicolumn{3}{|l|}{ Storm characteristics } \\
\hline 6. Minimum detection & $\begin{array}{l}\text { Minimum reflectivity threshold used to } \\
\text { detect the storm }\end{array}$ & {$[\mathrm{dBZ}]$} \\
\hline 7. Average reflectivity & $\begin{array}{l}\text { Average reflectivity of the storm considering } \\
\text { the entire area }\end{array}$ & {$[\mathrm{dBZ}]$} \\
\hline
\end{tabular}




\begin{tabular}{|c|l|c|}
\hline 8. Maximum reflectivity & $\begin{array}{l}\text { Maximum reflectivity of the storm } \\
\text { considering the entire area }\end{array}$ & {$[\mathrm{dBZ}]$} \\
\hline 9. Area & Storm area & {$\left[\mathrm{km}^{2}\right]$} \\
\hline 10. Velocity & Storm velocity and direction & {$\left[\mathrm{km} / \mathrm{h}, 0-360^{\circ}\right]$} \\
\hline 11. Hail $-\mathrm{POH}$ & $\begin{array}{l}\text { Distribution of POH values considering the } \\
\text { entire area }\end{array}$ & {$[\mathrm{mm}]$} \\
\hline 12. Hail $-\mathrm{MESHS}$ & $\begin{array}{l}\text { Distribution of MESHS values considering } \\
\text { the entire area }\end{array}$ & $\begin{array}{l}\text { Number and exact time of storm splitting } \\
\text { process, considering the whole storm life } \\
\text { cycle }\end{array}$ \\
\hline 13. Split & & \\
\hline
\end{tabular}

Table 2: list of storm parameters stored in the hail storm database.

\section{Appendix 2: list of acronyms}

CEST: Central European Summer Time

COSMO: COnsortium for Small-scale Modelling

COSMO-CH:COSMO Switzerland

COSMO-1: COSMO $1.0 \mathrm{~km}^{2}$ resolution

COSMO-2: COSMO $2.2 \mathrm{~km}^{2}$ resolution

COSMO-7: COSMO $6.6 \mathrm{~km}^{2}$ resolution

CSI: $\quad$ Critical Success Index

ET45: $\quad 45 \mathrm{dBZ}$ Echo Top height

ET50: $\quad 50 \mathrm{dBZ}$ Echo Top height

FAR: $\quad$ False Alarm Rate

Ho: $\quad$ freezing level height

HST: Hail Streaks

HSW: Hail Swath

MESH: $\quad$ Maximum Estimated Size of Hail

MESHS: Maximum Expected Severe Hail Size

NAO: $\quad$ North Atlantic Oscillation

NWP: $\quad$ Numerical Weather Prediction 


$\begin{array}{ll}\text { POD: } & \text { Probability Of Detection } \\ \text { POH: } & \text { Probability Of Hail } \\ \text { POSH: } & \text { Probability of Severe Hail } \\ \text { SHI: } & \text { Severe Hail Index } \\ \text { SPA: } & \text { Storm Path } \\ \text { STD: } & \text { Standard Deviation } \\ \text { TRT: } & \text { Thunderstorm Radar Tracking } \\ \text { UTC: } & \text { Universal Time Coordinated } \\ \text { VIL: } & \text { Vertically Integrated Liquid } \\ \text { WT: } & \text { Weather Type }\end{array}$

\section{Acknowledgments}

The authors thank M. Boscacci, L. Clementi, and I. Sideris (MeteoSwiss) for their technical support and all colleagues at MeteoSwiss in Locarno-Monti and the members of the EUMETSAT - ESSL Convection Working Group for scientific discussion and suggestions.

\section{References}

Basara JB, Cheresnick DR, Mitchell D, Illston B. 2007. An Analysis of Severe Hail Swaths in the Southern Plains of the United States. Transaction in GIS, 11(4): 531-554.

Besic N, Figueras i Ventura J, Grazioli J, Gabella M, Germann U, Berne A. 2016. Hydrometeor classification through statistical clustering of polarimetric radar measurements: a semi-supervised approach. Atmos. Meas. Tech., 9: 4425-4445. doi:10.5194/amt-9-44252016.

Betschart M, Hering A. 2012. Automatic hail detection at MeteoSwiss. Arbeitsberichte der MeteoSchweiz 238: 61. 
http://www.meteoschweiz.admin.ch/content/dam/meteoswiss/en/Ungebundene-

Seiten/Publikationen/Fachberichte/doc/ab238.pdf (accessed 01 October 2017).

Bluestein HB, McCaul Jr. EW, Byrd GP. 1990. An Observational Study of Splitting Convective Clouds. Mon. Wea. Rev. 118: 1359-1370.

Botzen WJW, van den Bergh JCJM, Bouwer LM. 2010. Climate change and increased risk for the insurance sector: a global perspective and an assessment for the Netherlands. Nat. Hazards, 52: 577. doi:10.1007/s11069-009-9404-1

Cacciamani C, Battaglia F, Patruno P, Pomi L, Selvini A, Tibaldi S. 1995. A Climatological Study of Thunderstorm Activity in the Po Valley. Theor. Appl. Climatol., 50: 185-203

Casty C, Wanner H, Luterbacher J, Esper J, Böhm R. 2005. Temperature and precipitation variability in the European Alps since 1500. Int. J. Climatol., 25: 1855-1880. doi:10.1002/joc. 1216

Changnon Jr SA. 1970. Hailstreaks. J. Atmos. Sci., 27 (1): 109-125.

Cintineo JL, Smith TM, Lakshmanan V. 2012. An Objective High-Resolution Hail Climatology of the Contiguous United States. Weather and Forecasting, 27: 1235-1248.

Collier CG, Lilley RBE. 1994. Forecasting thunderstorm initiation in north-west Europe using thermodynamic indices, satellite and radar data. Meteorol. Appl., 1: 74-84.

Crane RK. 1979. Automatic cell detection and tracking. IEEE Trans. Geosci. Electron.,GE$17,250-262$. 
Davolio S, Buzzi A, Malguzzi P. 2009. Orographic triggering of long lived convection in three dimensions. Meteorol. Atmos. Phys., 103: 35-44.

Dee DP, Uppala SM, Simmons AJ, Berrisford P, Poli P, Kobayashi S, Andrae U, Balmaseda MA, Balsamo G, Bauer P, Bechtold P, Beljaars ACM, van de Berg L, Bidlot J, Bormann N, Delsol C, Dragani R, Fuentes M, Geer AJ, Haimberger L, Healy SB, Hersbach H, Hólm EV, Isaksen L, Kållberg P, Köhler M, Matricardi M, McNally AP, Monge-Sanz BM, Morcrette JJ, Park B-K, Peubey C, de Rosnay P, Tavolato C, Thépaut J-N, Vitart F. 2011. The ERAInterim reanalysis: configuration and performance of the data assimilation system. Q.J.R. Meteorol. Soc., 137: 553-597. doi: 10.1002/qj.828

Delobbe L, Holleman I, Dehenauw D, Nem'eghaire J. 2005. 'Verification of radar-based hail detection products.' In Proceedings of the WWRP Symposium on Nowcasting and Very Short Range Forecasting (WSN05), 5-9 September 2005. Toulouse, France.

Dixon M, Wiener G. 1993. TITAN: Thunderstorm Identification, Tracking, Analysis and Nowcasting - A radar-based methodology. J. Atmos. Oceanic Technol., 10: 785-797.

Donaldson R. 1961. Radar reflectivity profiles in thunderstorms. J. Meteor. 18: 292-305.

Feudale L, Shukla J. 2011. Influence of sea surface temperature on the European heat wave of 2003 summer. Part I: An observational study. Clim. Dynam. 36: 1691-1703. doi:10.1007/s00382-010-0788-0

Foote GB, Knight CA. 1977: Hail: A Review of Hail Science and Hail Suppression. American Meteorological Society. 
Foote GB, Krauss TW, Makitov V. 2005. Hail metrics using convectional radar. In Proceedings of 16th Conference on Planned and Inadvertent Weather Modification, 10-13 January 2005. San Diego, CA: 1-6. American Meteorological Society: Boston.

Germann U, Galli G, Boscacci M, Bolliger M. 2006. Radar precipitation measurement in a mountainous region. Q. J. R. Meteorol. Soc. 132: 1669-1692.

Germann U, Boscacci M, Gabella M, Sartori M. 2015. Radar design for prediction in the Swiss Alps. Meteor. Techn. Int. 4: 42-45.

Germann U, Boscacci M, Gabella M, Schnebeli M. 2016. Weather radar in Switzerland. In Willemse S and Furger M (Eds.), From weather observations to atmospheric and climate sciences in Switzerland. (pp.165 - 185). vdf Hochschulverlag AG ETH Zuerich: Zuerich, Switzerland.

Germann U, Nerini D, Sideris I, Foresti L, Hering A, Calpini B. 2017. Real-Time Radar - A new Alpine Radar Network. Meteor. Techn. Int., 4: 88 - 92.

Giaiotti D, Nordio S, Stel F. 2003. The climatology of hail in the plain of Friuli Venezia Giulia. Atmos. Res. 67-68: 247-259.

Greene D, Robert R, Clark A. 1972. Vertically integrated liquid water -a new analysis tool. Mon. Wea. Rev. 100: 548-552. 
Hagen M, van Baelen J, Richard E. 2011. Influence of the wind profile on the initiation of convection in mountainous terrain. Q.J.R. Meteorol. Soc., 137: 224-235. doi:10.1002/qj.784

Hanley KE, Kirshbaum DJ, Belcher SE, Roberts NM, Leoncini G. 2011. Ensemble predictability of an isolated mountain thunderstorm in a high-resolution model. Q. J. R. Meteorol. Soc. 137: 2124-2137. DOI:10.1002/qj.877.

Hering AM, Morel C, Galli G, Sénési S, Ambrosetti P, Boscacci M. 2004. Nowcasting thunderstorms in the Alpine region using a radar based adaptive thresholding scheme. In Proceedings of 3rd European Conference Radar in Meteorology and Hydrology (ERAD), 610 September 2004, Visby, Sweden. 1-6. Copernicus: Goettingen, Germany.

Hering AM, Germann U, Boscacci M, Sénési S. 2008. Operational nowcasting of thunderstorms in the Alps during MAP D-PHASE. In Proceedings of 5th European Conference on Radar in Meteorology and Hydrology (ERAD), 30 June-4 July 2008, Helsinki, Finland. 1-5. Copernicus: Goettingen, Germany.

Huntrieser H, Schiesser HH, Schmidt W, Waldvogel A. 1997. Comparison of traditional and newly developed thunderstorm indices for Switzerland. Weather and Forecasting, 12: 108125.

Joe P, Burgess D, Potts R, Keenan T, Stumpf G, Treloar A. 2004. The S2K severe weather detection algorithms and their performance. Weather and Forecasting, 19: 43-63. 
Johns RH, Doswell III CA. 1992. Severe local storms forecasting. Weather and Forecasting, 7: $588-612$.

Johnson JT, MacKeen P, Witt A, Mitchell ED, Stumpf G, Eilts M, Thomas K. 1998. The storm cell identification and tracking algorithm: An enhanced WSR-88D algorithm. Weather and Forecasting, 13: 263-276.

Joss J, Schaedler B, Galli G, Cavalli R, Boscacci M, Held E, Della Bruna G, Kappenberger G, Nespor V, Spiess R. 1998. Operational Use of Radar for Precipitation Measurements in Switzerland. vdf Hochschulverlag AG ETH Zuerich: Zuerich, Switzerland. Available on: http://www.meteoswiss.admin.ch/content/dam/meteoswiss/fr/Mess-und-

Prognosesysteme/doc/meteoswiss_operational_use of radar.pdf (accessed 02 May 2017).

Kelly DL, Schaefer JT, Doswell III CA. 1985. Climatology of nontornadic severe thunderstorm events in the United States. Mon. Wea. Rev., 113 (11): 1997-2014.

Klemp JB, Wilhelmson RB. 1978. Simulations of right-and left-moving storms produced through storm splitting. J. Atmos. Sci., 35: 1097-1110.

Knight CA, Miller LJ. 1993. First radar echoes from cumulus clouds. Bull. Amer. Meteor. Soc., 74: 179-188.

Knight CA, Knight NC. 2001. Hailstorms. Severe Convective Storms, Meteor. Monogr. Amer. Meteor. Soc., 50: 223-254. 
Kottmeier C, Kalthoff N, Bathlott C, Corsmeier U, Van Baelen J, Behrendt A, Behrendt R, Blyth R, Coulter R, Crewell S, Di Girolamo P, Dorninger M, Flamant C, Foken T, Hagen M, Hauck C, Hoeller H, Konow H, Kunz M, Mahlke H, Mobbs S, Richard E, Steinacker R, Weckwerth T, Wieser A, Wulfmeyer V. 2008. Mechanisms initiating deep convection over complex terrain during COPS. Meteorol. Z. 6: 931-948.

Kunkel KE, Karl TR, Brooks H, Kossin J, Lawrimore JH, Arndt D, et al. 2013. Monitoring and understanding trends in extreme storms: state of knowledge. Bull. Am. Meteorol. Soc. 94: 499-514.

Kunz M, Puskeiler M. 2010. High-resolution assessment of the hail hazard over complex terrain from radar and insurance data. Meteorol. Z., 19 (5): 427-439

Kunz M, Kugel PSI. 2015. Detection of hail signatures from single-polarization C-band radar reflectivity. Atmos. Res., 153: 565-577.

López L, García-Ortega E, Sánchez JL. 2007. A short-term forecast model for hail. Atmos. Res. 83: 176-184.

Lukach M, Foresti L, Giot O, Delobbe L. 2017. Estimating the occurrence and severity of hail based on 10 years of observations from weather radar in Belgium. Meteorol. Appl. 24.2: 250259. DOI: $10.1002 /$ met. 1623

Madonna E, Ginsbourger D, Martius O. 2018. A Poisson regression approach to model monthly hail occurrence in Northern Switzerland using large-scale environmental variables. Atmos. Res. 203: 261-274.

Markowski P, Richardson Y. 2010. Mesoscale Meteorology in Midlatitudes. John Wiley \& Sons: West Sussex, UK, doi: 10.1002/9780470682104. 
Martius O, Hering A, Kunz M, Manzato A, Mohr S, Nisi L, Trefalt S. 2017. Challenges and recent Advances in Hail Research - A report from the $2^{\text {nd }}$ European Hail Workshop. Bull. Amer. Meteor. Soc. doi:10.1175/BAMS-D-17-0207.1, in press.

McGinley J. 1986. Nowcasting mesoscale phenomena. In Mesoscale Meteorology and Forecasting. American Meteorological Society, 657-688.

Mecikalski JR, Bedka KM. 2006. Forecasting convective initiation by monitoring the evolution of moving cumulus in daytime GOES imagery. Mon. Wea. Rev., 134: 49-78.

Mecikalski JR, Bedka KM, Paech SJ, Litten LA. 2008. A statistical evaluation of GOES cloud-top properties for nowcasting convective initiation. Mon. Wea. Rev., 136: 4899-4914.

Mecikalski JR, Mackenzie WM, Koenig M, Muller S. 2010. Use of Meteosat Second Generation infrared data in 0-1 hour convective initiation nowcasting. Part 1. Infrared fields. J. Appl. Meteorol., 49: 521-534.

Mecikalski JR, Li X, Carey LD, McCaul EW, Coleman TA. 2013. Regional comparison of GOES cloud-top properties and radar characteristics in advance of first-flash lightning initiation. Mon. Wea. Rev., 141: 55-74.

Melcón P, Merino A, Sánchez JL, López L, García-Ortega E. 2017. Spatial patterns of thermodynamic conditions of hailstorms in southwestern France. Atmos. Res. 189: 111-126.

Mohr S, Kunz M, Keuler K. 2015. Development and application of a logistic model to estimate the past and future hail potential in Germany. Journal of Geophys. Res.: Atmospheres, 120(9): 3939-3956. 
Morel S. 2014. 'Verification of radar-based hail detection algorithms with insurance loss data in Switzerland', Masters thesis. Faculty of Science, University of Bern, Switzerland. Available on: http://occrdata.unibe.ch/students/theses/msc/131.pdf (accessed 01 October 2017).

Mroz K, Battaglia A, Lang TJ, Cecil DJ, Tanelli S, Tridon F 2017: Hail-Detection Algorithm for the GPM Core Satellite Sensors. J. Appl. Meteor. Climatol. doi:10.1175/JAMC-D-160368.1 (in press).

Nisi L, Ambrosetti P, Clementi L. 2014. Nowcasting severe convection in the Alpine region: the COALITION approach. Q.J.R. Meteorol. Soc., 140: 1684-1699. doi: 10.1002/qj.2249

Nisi L, Martius O, Hering A, Kunz M, Germann U. 2016. Spatial and temporal distribution of hailstorms in the Alpine region: a long-term, high resolution, radar-based analysis. Q.J.R. Meteorol. Soc., 142: 1590-1604. doi:10.1002/qj.2771

Noti P. 2016. 'Hailstorms over Switzerland Verification of Radar-Based Hail Detection Algorithms with Crowd-Sourced App Data and Hail Sensor Data', Master thesis. Faculty of Science, University of Bern, Switzerland. Available on:

http://csold.unibe.ch/students/theses/msc/192.pdf (accessed 01 October 2017).

Panziera L, Germann U, Gabella M and Mandapaka PV. 2011. NORA-Nowcasting of Orographic Rainfall by means of Analogues. Q.J.R. Meteorol. Soc., 137: 2106-2123. doi:10.1002/qj.878

Panziera L., James CN, Germann U. 2015. Mesoscale organization and structure of orographic precipitation producing flash floods in the Lago Maggiore region. Q.J.R. Meteorol. Soc., 141: 224-248. doi:10.1002/qj.2351

Piper D, Kunz M. 2017. Spatio-temporal variability of lightning activity in Europe and the 
relation to the North Atlantic Oscillation teleconnection pattern. Nat. Hazards Earth Syst. Sci. Discuss. doi:10.5194/nhess-2017-35.

Punge HJ, Kunz M. 2016. Hail observations and hailstorm characteristics in Europe: a review Atmos. Res., 176-177: 159-184

Punge HJ, Bedka KM, Kunz M, Reinbold A. 2017. Hail frequency estimation across Europe based on a combination of overshooting top detections and the ERA-INTERIM reanalysis. Atmos. Res., 198: 34-43.

Puskeiler M. 2013. Radarbasierte analyse der hagelgefährdung in deutschland. $\mathrm{PhD}$ Thesis. Institute of Meteorology and Climate Research, Karlsruhe Institute of Technology (KIT), Karlsruhe, Germany. 206 pp.

Rajeevan M, Kesarkar A, Thampi SB, Rao TN, Radhakrishna B, Rajasekhar M. 2010. Sensitivity of WRF cloud microphysics to simulations of a severe thunderstorm event over Southeast India. Annales geophysicae: atmospheres, hydrospheres and space sciences. 28(2): $603-619$.

Riemann-Campe K, Blender R, Fraedrich K. 2010. Global memory analysis in observed and simulated CAPE and CIN. Int. J. Climatol., 31(8): 1099-1107.

Roberts RD, Rutledge S. 2003. Nowcasting storm initiation and growth using GOES-8 and WSR-88D data. Weather and Forecasting, 18: 562-584.

Rohrer M. 2013. Climate Change and Circulation Types in the Alpine Region, Arbeitsberichte der MeteoSchweiz, 91, 80 pp. Available on: http://www.meteoschweiz.admin.ch/content/dam/meteoswiss/en/UngebundeneSeiten/Publikationen/Scientific-Reports/doc/sr91rohrer.pdf (accessed 02 May 2017). 
Rotach MW, Ambrosetti P, Ament F, Appenzeller C, Arpagaus M, Bauer HS, Behrendt A, Bouttier F, Buzzi A, Corazza M, Davolio S, Denhard M, Dorninger M, Fontannaz L, Frick J, Fundel F, Germann U, Gorgas T, Hegg C, Hering A, Keil C, Liniger MA, Marsigli C, McTaggart-Cowan R, Montaini A, MylneK, Ranzi R, Richard E, Rossa A, Santos-Munoz D, Schaer C, Seity Y, Staudinger M, Stoll M, Volkert H, Walser A, Wang Y, Werhahn J, Wulfmeier W, Zappa M. 2009. MAP D-PHASE: Real-time demonstration of weather forecast quality in the Alpine region. Bull. Am. Meteorol. Soc. 90: 1321-1336.

Rotunno R, Klemp JB. 1982. The influence of the shear-induced pressure gradient on thunderstorm motion. Mon. Wea. Rev., 110: 136-151.

Saltikoff E, Tuovinen JP, Kotro J, Kuitunen T, Hohti H. 2010. A climatological comparison of radar and ground observations of hail in Finland. J. Appl. Meteorol. Clim. 49: 101-114, doi: 10.1175/2009JAMC2116.1.

Sanders F. 1986. Explosive cyclogenesis in the west-central North Atlantic Ocean, 1981-84. Part I: Composite structure and mean behavior. Mon. Wea. Rev., 114: 1781-1794.

Schär C, Jendritzky G. 2004. Hot news from summer 2003. Nature, 432: 559-560.

Schemm S, Nisi L, Martinov A, Leuenberger D, Martius O. 2016. On the link between cold fronts and hail in Switzerland. Atmos. Sci. Lett., 17: 315-325. doi:10.1002/asl.660

Schiesser HH, Houze Jr. RA, Huntrieser H. 1995. The mesoscale structure of severe precipitation systems in Switzerland. Mon. Wea. Rev., 123: 2070-2097.

Schlesinger RE. 1980. A three-dimensional numerical model of an isolated thunderstorm. Part II: Dynamics of updraft splitting and mesovortex couplet evolution. J. Atmos. Sci., 37: 395420. 
Schmid W, Fovell RG, Schiesser HH. 1993. Hailstorms in Switzerland: Left movers, right movers, and false hooks. Mon. Wea. Rev., 121: 3345-3370.

Skripniková K., Řezáčová D. 2014. Radar-based hail detection. Atmos. Res., 144: 175-185.

Sokol Z, Bližňák V, Zacharov P, Skripniková K. 2016. Nowcasting of hailstorms simulated by the NWP model COSMO for the area of the Czech Republic. Atmos. Res., 171: 66-76.

Spiridonov V, Dimitrovski Z, Curic M. 2010. A three-dimensional simulation of supercell convective storm. Advances in Meteorology, 1 - 15. doi:10.1155/2010/234731

Stull RB. 1985. A Fair-Weather Cumulus Cloud Classification Scheme for Mixed-Layer Studies. J. Climate Appl. Meteor., 22: 1022-1040.

Trefalt S, Martynov, A, Barras H, Besic N, Hering A, Lenggenhager S, Noti P, Roethlisberger M, Schemm S, Germann U, Martius O. (submitted to Atmos. Res.). A multi-data process study of a severe hail storm in complex topography.

Treloar ABA. 1998. Vertically integrated radar reflectivity as an indicator of hail size in the Greater Sydney region of Australia. In Proceedings of $19^{\text {th }}$ Conference on Severe Local Storms, 14-18 September 1998. Minneapolis, MN: 48-51. American Meteorological Society: Boston.

Van Delden A. 2001. The synoptic setting of thunderstorms in western Europe. Atmos. Res., 56: $89-110$.

Vinet F. 2001. Climatology of hail in France. Atmos. Res. 56: 309-323.

Waldvogel A, Federer B, Grimm P. 1979. Criteria for the detection of hail cells. J. Appl. Meteorol., 18: 1521-1525.

Wapler K, Hengstebeck T, Groenemeijer P. 2016. Mesocyclones in Central Europe as seen by radar. Atmos. Res., 168: 112-120. 
Weckwerth TM, Wilson JW, Hagen M, Emerson TJ, Pinto JO, Rife DL, Grebe L. 2011. Radar climatology of the COPS region. Q.J.R. Meteorol. Soc., 137: 31-41. doi:10.1002/qj.747

Weusthoff T. 2011. Weather Type Classification at MeteoSwiss - Introduction of new automatic classifications schemes, Arbeitsberichte der MeteoSchweiz, 235, 46 pp. Available on: $\quad$ http://www.meteoschweiz.admin.ch/content/dam/meteoswiss/en/UngebundeneSeiten/Publikationen/Fachberichte/doc/ab235.pdf (accessed 2 May 2017).

Wicker LJ, Wilhelmson RB. 1995. Simulation and analysis of tornado development and decay within a three-dimensional supercell thunderstorm. J. Atmos. Sci., 52: 26752703.doi:https://doi.org/10.1175/1520-0469(1995)052<2675:SAAOTD>2.0.CO;2.

Wilks DS. 2006. Statistical Methods in the Atmospheric Sciences: An Introduction (2nd edn). Amsterdam: Academic Press.

Wilson JW, Crook NA, Mueller CK, Sun J, Dixon M. 1998. Nowcasting thunderstorms: A status report. Bull. Am. Meteorol. Soc., 79: 2079-2099.

Witt A, Eilts MD, Stumpf GJ, Johnson JT, Mitchell ED, Thomas KW. 1998. An enhanced hail detection algorithm for the WSR-88D. Weather and Forecasting, 13: 286-303. 